\title{
A Lost Ottoman Square in a Lost Harbour of Istanbul: Kontaskalion / Kadirga Harbour / Kadirga Square*
}

\author{
İstanbul'un Kayıp Bir Limanında Kayıp Bir Osmanlı Meydanı: Kontaskalion / Kadırga \\ Limanı / Kadırga Meydanı
}

\author{
Selman Çelik ${ }^{\star *}$ (D), Nuran Kara Pilehvarian*** (D)
}

\begin{abstract}
Squares, which are one of the architectural features of cities, have an important place in the field of history of architecture. In the literature, starting from the first ages especially, the notion of square is reached through architectural factors like agora, forum, piazza and etc. and regional and periodic typologies were tried to be produced. However, these studies are limited to general studies, such as Ancient Greek squares, Ancient Roman squares, Medieval squares, Renaissance squares, etc. and the large urban squares known around the world. Neighbourhood squares have been ignored. In addition, because the concept of the square in the Ottoman period was tried to be evaluated through the concept of the square in European countries in the sources, the Ottoman's unique understanding of the square have been overlooked. In this study, Kadirga Square, located in the historical peninsula of Istanbul, has been chosen among the Ottoman squares. Kadirga Square, its functions and its historical process have been examined by taking the notion of square into the centre. The function and effect of Kadirga Harbour, the formation process of Kadirga Square, the elements forming the square and its intended uses, the transformation process into a park and the process of the disappearance of the square's functions have been evaluated in terms of the history of architecture. Through Kadirga Square in the Ottoman period, it was aimed to contribute to the field of history of architecture by making an evaluation of a neighbourhood square that was not designed.
\end{abstract}

\section{Keywords}

Square, Ottoman Square, Kadirga, Kadirga Square, Kadirga Harbour

\section{Öz}

Kentlerin mimari öğelerinden biri olan meydanlar, mimarlık tarihi alanında önemli bir yer tutar. Literatürde özellikle ilk çağlardan başlayarak agora, forum, piazza vb. mimari öğeler üzerinden nihayetinde meydan kavramına ulaşılarak bölgesel ve dönemsel tipolojiler üretilmeye çalışılmıştır. Ancak bu çalışmalar; Antik Yunan meydanları, Antik Roma meydanları, Orta Çağ meydanları, Rönesans meydanları vb. genel çalışmalar ile birlikte dünya genelinde bilinen büyük kentsel meydanlar

* This paper was produced from the PhD thesis titled "Squares in the Ottoman Capital Istanbul" prepared by Selman Çelik and supervised by Prof. Dr. Nuran Kara Pilehvarian at Yildiz Technical University, Graduate School of Science and Engineering, Department of Architecture, History and Theory of Architecture Program.

** Correspondence to: Selman Çelik (PhD Student), Yildiz Technical University, Faculty of Architecture, Department of Architecture, History and Theory of Architecture Program, Istanbul, Turkey. E-mail: selman@selmancelik.info, ORCID: 0000-0001-5945-5825

*** Nuran Kara Pilehvarian (Prof. Dr.), Yildiz Technical University, Faculty of Architecture, Department of Architecture, History of Architecture Unit, Istanbul, Turkey. E-mail: pvarian@gmail.com, ORCID: 0000-0002-0021-2076

To cite this article: Celik, Selman and Kara Pilehvarian, Nuran. "A Lost Ottoman Square in a Lost Harbour of Istanbul: Kontaskalion / Kadirga Harbour / Kadirga Square." Art-Sanat, 16(2021): 55-85.

https://doi.org/10.26650/artsanat.2021.16.0003 
üzerinde sınırlandırılmıştır. Semt meydanları göz ardı edilmiştir. Ayrıca, kaynaklarda Osmanlı döneminde meydan kavramı Avrupa ülkelerindeki meydan kavramı üzerinden değerlendirilmeye çalışıldığı için Osmanlı'nın kendine özgü meydan anlayışı yeterince tartışılmamıştır. Bu çalışmada Osmanlı meydanları arasından İstanbul'da tarihî yarımadada bulunan Kadırga Meydanı seçilmiştir. Kadırga Meydanı ve işlevleri tarihsel süreci ile birlikte meydan kavramı merkeze alınarak incelenmiştir. Kadırga Limanı'nın işlevi ve etkisi, Kadırga Meydanı'nın oluşum süreci, meydanı oluşturan unsurlar ve kullanım amaçları, parka dönüştürülmesi ve sonrasında meydan işlevlerinin yok olması süreci mimarlık tarihi açısından değerlendirilmiştir. Kadırga Meydanı üzerinden Osmanlı döneminde tasarlanmamış bir semt meydanı okuması yapılarak mimarlık tarihi alanına katkı verilmesi amaçlanmıştır.

Anahtar Kelimeler

Meydan, Osmanlı Meydanı, Kadırga, Kadırga Meydanı, Kadırga Limanı

\section{$\underline{\text { Genisletilmis Özet }}$}

Kadırga Meydanı, Bizans döneminde kurulan ve 1453 'te İstanbul'un fethi ile Osmanlı Devleti'nin eline geçerek Kadırga Limanı adını alan Kontaskalion'un tahminlere göre on altıncı yüzyıl içerisinde toprak ile dolması (ya da doldurulması) sonucu ortaya çıkan yeni kara parçasının kuzeyinde kalan bir meydandır. 1953 yılında parka dönüştürülmesi sonrası zamanla meydan yok olmuştur ve günümüzde de park olarak kullanılmaya devam etmektedir.

Bu makale kapsamında ilk olarak giriş bölümünde Avrupa kentlerinde meydanlar ile Osmanlı Devleti'nde meydanlar üzerine yapılmış araştırmalar ele alınmış ve ardından meydan kavramı meydan türleri, meydanların işlevleri ve özellikleri, meydanların sosyal hayata olan etkileri vb. yönlerden irdelenmiştir. Osmanlı Meydanları ayrı bir başlık altında değerlendirilmiş ve İstanbul'un meydanlarına dikkat çekilmiştir.

Makalenin odağında yer alan bölümler Kontaskalion, Kadırga Limanı, Kadırga Meydanı ve Kadırga Parkı'dır. Kontaskalion, Kadırga Limanı'nın Doğu Roma İmparatorluğu dönemindeki ismidir ve Osmanlı Dönemi öncesinde de bu alan bir liman ve tersane bölgesi olarak kullanılmıştır. Konstantinopolis'in 1453'te Fatih Sultan Mehmed tarafından fethedilmesinin ardından bu bölge önce liman ve tersane işlevlerini korumuş ancak zaman içerisinde toprak ile dolması sonucu bir kent boşluğu meydana çıkmıştır. Bu kent boşluğu ise çok kısa bir süre içerisinde bileşenlerinin oluşması sonucu bir semt meydanı olarak nitelendirilebilecek olan Kadırga Meydanı'na dönüşmüştür.

Kadırga Meydanı'nın bileşenleri, tarihsel süreç içerisindeki sırası gözetilerek Üsküplü Yahya Paşa Sıbyan Mektebi, Acı Su Çeşmesi, Bostanî Ali Camii, Kadırga Hamamı, Esma Sultan Çeşmesi, İsimsiz Çeşme, Tarihî Havuzlu Kahve, Kadırga İlkokulu, Kumkapı Polis Merkezi ve Kadırga Mesleki ve Teknik Anadolu Lisesi olarak tespit edilmiştir.

Kadırga sakinlerinin 1930'ların başında kış mevsiminde çamurun, yaz mevsiminde ise tozun çok olmasından dolayı meydandan şikâyet etmeye başlaması ile meydanın 
parka dönüştürülmesi fikri öne çıkmaya başlamıştır. Öyle ki, 1933’te mahalle sakinleri tarafından bir gazeteye çağrı ilanı dahi verilmiştir. 20 yıllık bir süreç sonrasında Kadırga Meydanı'nın boş kalan toprak alanı 1953 yılında düzenlenerek Kadırga Parkı'na dönüştürülmüştür. Parkın bu ilk düzenlenmiş hâli çocuk oyun alanı, küçük bir süs havuzu ve dinlenme alanlarından oluşmaktadır. Daha sonraki düzenlemelerde ise parkın merkezindeki süs havuzu genişletilmiş, dinlenme alanlarında bulunan banklar çoğaltılmış ve ağaçlar arasından yürüyüş yolları açılmıştır.

Kadırga Parkı günümüzde varlığını sürdürmektedir. Esma Sultan Çeşmesi, Kumkapı Polis Merkezi ve Tarihî Havuzlu Kahve, Kadırga Meydanı'ndan kalan eski unsurlar olarak park alanı içerisindedir. Kadırga Limanı Caddesi ve Kadırga Meydanı Sokağı, Kadırga Parkı'nın sınırlarını oluşturduğu için Kadırga İlkokulu, Kadırga Mesleki ve Teknik Anadolu Lisesi, İsimsiz Çeşme, Acı Su Çeşmesi, Bostanî Ali Camii, Üsküplü Yahya Paşa Sıbyan Mektebi ve Kadırga Hamamı parkın dışında kalmıştır. Ancak bugün parkın içinde başka unsurlar da bulunmaktadır: Kadırga Spor Kulübü’nün tek katlı binası (Kumkapı Polis Merkezi’nin arkasında kulüp üyeleri ve kurucular için küçük bir çayevi), mahalle muhtarlığı (Esma Sultan Çeşmesi’nin yanında), Kadırga Çay Bahçesi (Esma Sultan Çeşmesi’nin yanında küçük bir kafe). Bunların dışında bugün parkın merkezinde daha büyük bir süs havuzu, kuzeyde kauçuk zeminle kaplı daha büyük ve modern bir çocuk oyun alanı, daha fazla sayıda ağaç ve bitkilerin çevresinde daha fazla sayıda bank yer almaktadır. Parkın zemini artık toprak yerine parke taşı döşelidir ve çim alanlar deformasyonu önlemek için siyah demir korkuluklarla çevrilmiştir.

Avrupa şehirlerinde olduğu gibi planlı ve tasarlanmış bir meydan olmasa da Kadırga Meydanı'nın Avrupa meydanlarındakine benzer amaçlarla kullanıldığı açıkça söylenebilir. Çevresindeki binalar tüm şehir için öncelikli unsurlar olmadığından ve meydanın kapladığı alanın büyüklüğü bütün kent sakinleri düşünüldüğünde yeterli olmadığından dolayı Kadırga Meydanı bir kent meydanı olarak nitelendirilemez. Ancak bölge sakinleri açısından değerlendirildiğinde Kadırga Meydanı beklentileri fazlasıyla karşılamaktadır. Meydanın tarihi, mimari ve kentsel süreci, eski fotoğrafları ve mahalle sakinlerinin anlatıları, meydanın gerçek bir semt meydanı olarak kullanıldığını göstermektedir.

Kadırga Meydanı'nın sınırları dâhilinde herhangi bir yapılaşmaya izin verilmemesi ve hatta izinsiz yapıların meydanın erken devrinde Köprülü Mehmed Paşa tarafından yıktırılması, Osmanlı'da meydanların rastlantısal olmadığına ve kendi kültür kodları içerisinde bir meydan kavramının bulunduğuna örnek teşkil etmektedir.

Tarihsel süreç içerisinde meydanın bileşenleri birlikte ele alındığında bu meydanın Osmanlı'da meydan kavramı çerçevesinde uzun bir süreç içerisinde ancak bilinçli bir şekilde oluştuğu anlaşılmaktadır. Doğu Roma İmparatorluğu'ndan kalan Kontaskalion'un Kadırga Limanı olarak kullanılmaya devam etmesi ile burada bir 
liman meydanının oluştuğu ve daha sonra alanın toprak dolması sonucu meydanın süreç içerisinde yeni işlevleri ile bir semt meydanı olan Kadırga Meydanı'na dönüştüğü söylenebilir. Meydana yüklenen işlevlerden; toplanma alanı olması, semt sakinlerinin geneline hitap eden ve hizmet veren yapıların (mektep, çeşme vb.) burada inşa edilmesi, kutlamalar ve eğlenceler için bayram yerinin ve geçici tiyatroların burada kurulması, futbol maçlarının ve düzenli antrenmanların Kadırga Parkı'nın açılışına kadar burada yapılması vb. birçok inşa tercihi, olay ve etkinlik Kadırga Meydanı'nı öncül bir semt meydanı olarak öne çıkarmaktadır.

1953 yılında Kadırga Meydanı'nın Kadırga Parkı'na dönüşmesi meydan işlevleri açısından çok önemli bir dönüm noktası olmuştur. Park süreci ile birlikte meydanın tamamı rekreasyon alanına dönüşmüş ve meydan işlevleri zaman içerisinde yok olmuştur. Günümüzde bir park, bir çeşme veya parkın etrafındaki birçok çeşme bir meydan için ayırt edici unsurlar değildir. Bunun bir sonucu olarak Kadırga Meydanı bugün işlevleriyle birlikte kaybolmuştur. Bugün Kadırga Parkı'nın bulunduğu alanda daha önce bir semt meydanının olduğunun tek işareti parkı kısmen çevreleyen sokağın resmi adıdır: Kadırga Meydanı Sokağı. 


\section{Introduction}

It is essential to investigate cities and their life traces in these cities in order to reveal the cultural codes of civilisations. In this context, squares in cities are one of the primary research subjects. It is possible to read the collective life and culture codes of a region through the squares in cities, as well as making determinations of architecture and urbanism ${ }^{1}$. In the historical process, squares continue to be explored for these and similar purposes. In this study, the squares in the Ottoman period have been chosen as the research area and Kadirga Square has been focused on especially.

Although there is much research on the squares of European cities, the research on Ottoman Squares is very limited and does not include detailed reviews. Unfortunately, there is a common admission that there are no squares in the Ottoman period as in European cities except the inner and outer courtyards of selatin mosques (the mosques built by the Ottoman Sultans and their families) and some squares already left from the Roman Empire (such as the Hippodrome / Atmeydani, Forum Bovis / Aksaray Square, Forum Tauri / Beyazit Square in Istanbul) $)^{2}$. On the other hand, when looked from another perspective, Ottoman squares are not limited with courtyards of mosques $^{3}$. It can be accepted that most of the Ottoman Squares are not urban squares as in the European cities; however, they are squares anyway with their locations and local functions. Moreover, they can be categorised. For instance; Atmeydani as an urban square, the second courtyard of Topkapi Palace as a palace square, the courtyard of Fatih Mosque in Istanbul as a mosque square, Selimiye Talimhane Square as a military square, Cundi (Cinci) Square as a sport square, Uskudar Iskele Square as a pier square, Tophane Square as a fountain square, Dua Square in Kapalicarsi as a prayer square, and Kadirga Square as a neighbourhood square.

Kadirga Square was selected for this study because of its extraordinary story and its characteristic that shows how a neighbourhood square works in the Ottoman period. The study starts with the notion of square. And then respectively; Ottoman Squares, Kadirga Harbour - the harbour that was in the place of Kadirga Square before, Kadirga Square and the main elements of the square were examined. The transformation of Kadirga Square to Kadirga Park is also evaluated and the whole process of Kadirga Square was tried to be defined how the Ottomans see a square as users and local administrators of it with an urban eye in the conclusion section.

1 Ejder Ulutaş, “İmgeden Gerçekliğe: Kamusal Bir Mekan Olarak Meydan”, İçtimaiyat Sosyal Bilimler Dergisi 3/2 (2019), 138-146.

2 Sinan Genim, “Meydanlar Üzerine,” Milliyet, December 8, 2013, 28.

3 Genim, "Meydanlar Üzerine," 28. 


\section{Notion of Square}

Square, as a dictionary meaning, is a large and open area or place that is surrounded by natural barriers (trees, flora etc.) or buildings in order to gather people for different purposes $^{4}$. From a different perspective, squares are the places where people could discover their city and communicate with each other. For historical, social, cultural, political, ceremonial, sportive and many other reasons, squares are the most suitable places $^{5}$. According to Moughtin, squares are the areas that are surrounded by buildings and exhibit these surrounding buildings in the best way ${ }^{6}$. According to Krier, squares are the urban courtyards formed by the surrounding houses around an open $\operatorname{area}^{7}$. From a different view, Lynch entitles squares as nodal points where some characteristics are condensed ${ }^{8}$. In terms of social life, a square is in the centre and those who want to appear show up here. It is also a showcase and fingerprint of the city and culture. Every square has its own unique lines and codes. Each square shows different things. The squares where social memory is embodied host revolutions and great changes. Squares are indispensable areas for politicians to come to power. On the other hand, protesters also choose squares for their actions. In any case, the message intended is given to more people easily in squares ${ }^{9}$.

Squares can be examined in different categories according to their functions and features. For instance, the squares where more than one transportation network intersect and host heavy city traffic can be classified as traffic squares. Also, when squares contain a certain function of city life, for example a special event or a special structure, they are referred to the name of that function or structure such as ... Mosque Square, ... Fountain Square, ... Pier Square and ... Republic Square ${ }^{10}$. As a result of this, the concept of the square and the features of the surrounding structures have a great influence on the characteristics of the square ${ }^{11}$.

\section{Ottoman Squares}

The Ottoman Empire had cities in three different continents: Europe, Asia and Africa. Considering and observing the Ottoman cities of these continents, it can be

4 Doğan Hasol, "Meydan," Ansiklopedik Mimarllk Sözlüğ̈̈, (İstanbul: YEM Yayın, 2017), 320.

5 Jülide Kayalar, "Urban and Square - A Comparative Study of Revitalization Process," (MA diss. Mimar Sinan Fine Arts University. 2006), 24.

6 Cliff Moughtin, Urban Design: Street And Square (Amsterdam: Architectural Press, 2003), 87.

7 Rob Krier, Urban Space (London: Academy Editions, 1991), 17.

8 Kevin Lynch, Kent İmgesi (İstanbul: Türkiye İș Bankası Kültür Yayınları, 2010), 80.

9 Ulutaş, "İmgeden Gerçekliğe: Kamusal Bir Mekan Olarak Meydan", 138-146.

10 Çınar Altınçekiç, Hande Sanem and Nilüfer Kart, "Kentsel Tasarım Sürecinde Meydanlar", Istanbul Üniversitesi Orman Fakültesi Dergisi 50/2 (2000), 111-120.

11 Aybike Y1ldiz, "Historical Accumulations of Urban Open Space Dynamism - Istanbul Urban Example; Beyazit Square, Sultanahmet Square and Taksim Square," (MA diss. Istanbul Technical University. 2007), 12. 
said that there are no strict rules for each city to have a square or squares like having a grand mosque. However, there are different types of squares in Ottoman cities. Although Ottoman squares are different from the squares in Europe in terms of their size and arrangement, the functions of both Ottoman squares and European squares are quite similar to each other ${ }^{12}$.

Not every Ottoman square has to be surrounded by buildings. For instance, Sirik Square next to the New Edirne Palace has walls on two sides but the other sides are not limited with buildings or walls. This is because this type of square is more suitable for some events requiring more space. Hence, the square is organised and equipped differently in each case. Similarly, it is known that Atmeydani in Istanbul had some temporary organisations and even temporary grandstands set up in the square sometimes ${ }^{13}$.

The Ottoman Squares in the historical peninsula of Istanbul are different from the other cities. The monumental forums of Constantinople, which was the capital of the Eastern Roman Empire, are also important for Ottomans in terms of the creation of the image of the city. Some of these forums were used as squares for similar purposes in the Ottoman period, such as Tauri Forum's transformation to Beyazit Square ${ }^{14}$. In terms of geometrical features, it can be said that Ottoman Squares are not shaped around a central building. Even the monumental mosque in a square can be in the corner not in the middle of the square sometimes ${ }^{15}$ (In the Kadirga Square section, it will be seen that Kadirga Square is also a suitable sample to this opinion with the location of its mosque and fountains.). For Ottomans, Fatih Square (the courtyards of Fatih Mosque) has special importance. According to Kuban, Fatih Square is the only square that was planned and also can be defined as the only Turkish forum. In this context, this square is a unique sample for urban design in Ottoman architecture ${ }^{16}$. According to Çelik, courtyards of great mosques were the primary open spaces for everyone's use in the Ottoman period and both religious and secular functions were convened in these places ${ }^{17}$.

Although the information above about Ottoman squares is limited in the literature, the original differences of their intended use and features can be distinguished from European squares. It can be said that Ottoman squares are not highlighted as in the European cities. However, they meet people's expectations to a certain extent.

12 Ziya Gençel, “Geleneksel Türk Kentinde Meydan Kavramı”, Ege Mimarlık, 2000/2 (2000), 22-25.

13 Gençel, "Geleneksel Türk Kentinde Meydan Kavramı”, 23-24.

14 Gençel, "Geleneksel Türk Kentinde Meydan Kavramı", 24.

15 Gençel, "Geleneksel Türk Kentinde Meydan Kavramı", 25.

16 Doğan Kuban, İstanbul - Bir Kent Tarihi - Bizantion, Konstantinopolis, İstanbul (İstanbul: Türkiye İş Bankası Kültür Yayınları, 2017), 247.

17 Zeynep Çelik, 19. Yüzyılda Osmanlı Başkenti - Değişsen İstanbul (İstanbul:Türkiye İş Bankası Kültür Yayınları, 2016), 2. 


\section{Kontaskalion}

When the literature is examined, the area of Kadirga Harbour had different names throughout the history: Kontaskalion, Iulianus Harbour, Sophia Harbour, Kadirga Harbour. Initially, because of the population growth in Constantinople and incapacity of the old harbours, the construction of a new and larger harbour started in the period of Emperor Iulianus (361-363) in a bay of the South part of Constantinople ${ }^{18}$. In 465, the harbour had partial damage because of a fire. In the period of Anastasios I (491518), the harbour was cleaned with detecting tools and a new breakwater was built. However, a new fire in 561 affected the harbour. Thus, the harbour was rebuilt in 575 in the period of Iustinos II (565-578). This rebuilding includes a new cleaning at the bottom and a new enlargement of the harbour. After a while, the harbour was called Sophia Harbour. Sophia is the name of the wife of the emperor of that time. Sophia Harbour has four sculptures: Iustinos, Sophia, Arabia (their daughter) and Narses. Towards the end of the sixth century, the harbour became a war harbour ${ }^{19}$.

In the sources, a shipyard was built in the harbour in the period of Emperor Theophilos (829-842). In the thirteenth century, Michael VIII Palaiologos (12591282) rebuilt the harbour with the surrounding walls made of cut stones and the entry of the harbour was blocked by chains. It can be said that Kontaskalion is the only harbour of Constantinople used until the Ottoman period ${ }^{20}$. Muller-Wiener also states with reference to Buondelmonti that Kontaskalion was used as a shipyard and harbour complex until the Ottoman Period ${ }^{21}$.

18 Wolfgang Muller-Wiener, Bizans 'tan Osmanlı' ya İstanbul Limanı (İstanbul: Tarih Vakfi Yurt Yayınları, 1998), 8.

19 Wolfgang Muller-Wiener, İstanbul'un Tarihsel Topografyası - 17. Yüzyll Başlarına Kadar Byzantion-Konstantinopolis-İstanbul (İstanbul: Yapı Kredi Yayınları, 2001), 62.

20 Muller-Wiener, İstanbul'un Tarihsel Topografyası - 17. Yüzyll Başlarına Kadar Byzantion-Konstantinopolis-İstanbul, 62-63.

21 Muller-Wiener, Istanbul'un Tarihsel Topografyası - 17. Yüzyll Başlarına Kadar Byzantion-Konstantinopolis-İstanbul, 63. 


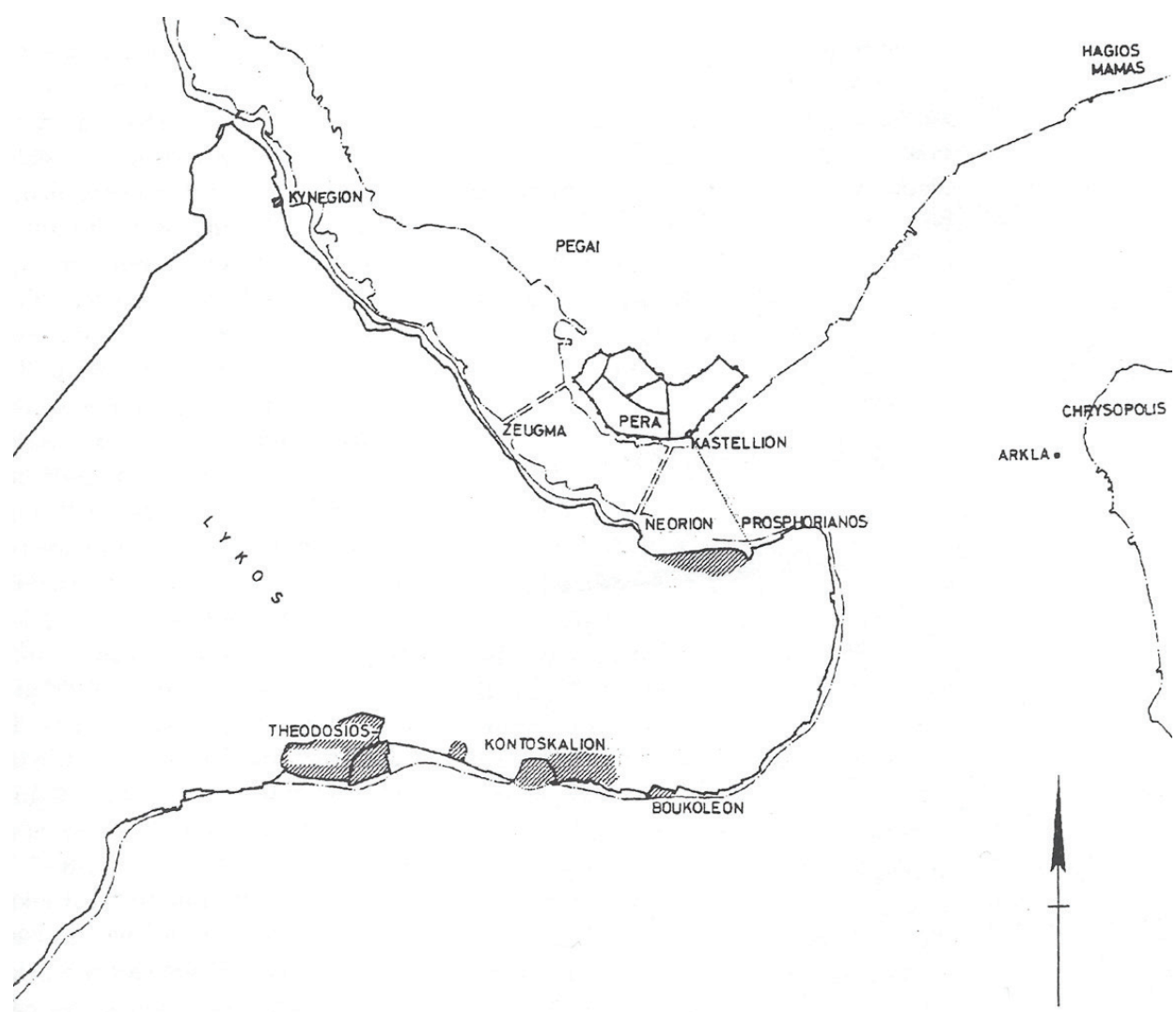

F. 1: Kontaskalion on Map of Constantinople Harbours (Muller-Wiener, Bizans 'tan Osmanlı'ya Ístanbul Limanı, 7)

\section{Kadirga Harbour}

After the conquest of Constantinople by the Ottoman Sultan Mehmed II (Fatih Sultan Mehmed) in 1453, the name of Kontaskalion Harbour was changed to Kadirga Harbour. Kadirga means galley (a type of war ship used between $8^{\text {th }}-17^{\text {th }}$ centuries in the Mediterranean that is propelled mainly by rowing. The galley is characterised by its long, slender hull, shallow draft, and virtually all types of galleys had sails that could be used in favourable winds, but human effort was always the primary method of propulsion) in the Turkish language as in the Greek language. Kadirga Harbour was used as a shipyard and harbour complex in the Ottoman Period as well and the old functions of the harbour were preserved. Because of Kadirga Harbour, the neighbourhood around the harbour was called Kadirga as well ${ }^{22}$. 


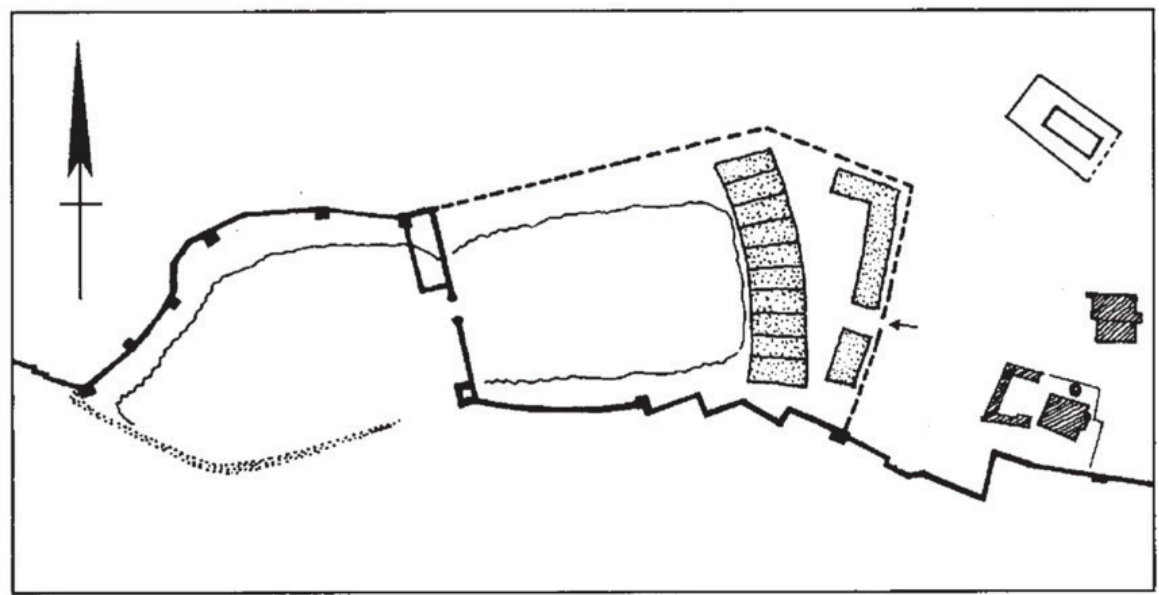

F. 2: Kadirga Harbour and the Shipyard, around 1500, Restitution (Muller-Wiener, Bizans 'tan Osmanlı'ya İstanbul Limanı, 42)

Muller-Wiener's restitution (F. 2) shows the shipyard and the harbour complex with details. The surrounding walls, the breakwater, the entrance of the harbour, the entrance of the shipyard, the special rectangle areas for galleys in the shipyard and the clearer boundaries of Kadirga Harbour with its surroundings can be examined. This drawing is also another piece of evidence of the continuity of functions between Kontaskalion and Kadirga Harbour. 


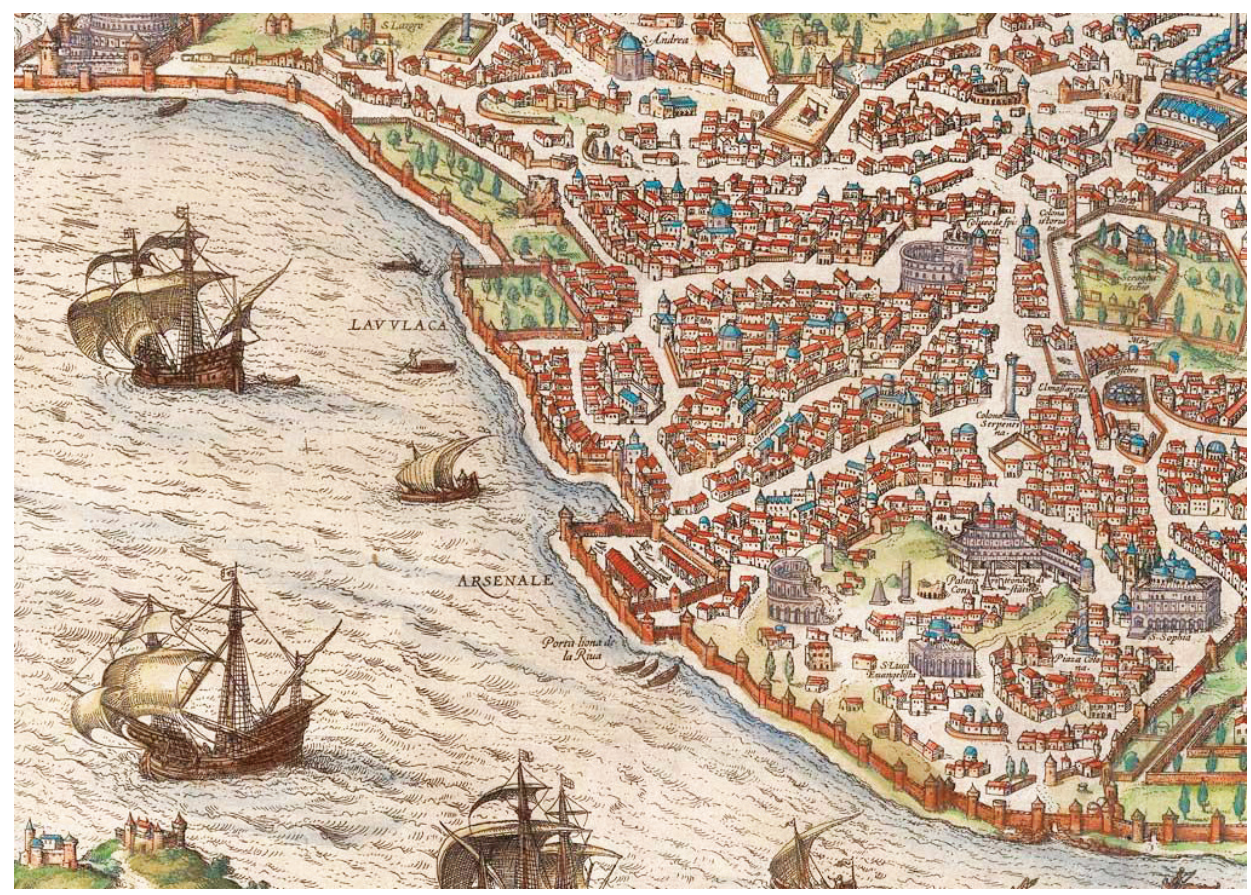

F. 3: Kadirga Harbour on Map of Constantinople (Braun and Hogenberg, Civitates Orbis Terrarum Volume I, 51)

Fatih Sultan Mehmed built defence towers in the harbour in 1462. However, because of the establishment of a shipyard in the Golden Horn (Halic Shipyard) in 1515 and the reinforcement of the Ottoman Navy in the sixteenth century, Kadirga Harbour started to lose its importance. However, an engraving by Braun and Hogenberg dated 1572 shows that the harbour's main function was still in use (F. 3). Pierre Gilles claims that women were washing their clothes in Kadirga Harbour in the $1540 \mathrm{~s}^{23}$. In 1748, the excavation soil of the construction of Nuruosmaniye Mosque was discharged to Kadirga Harbour. In the following years, Kadirga Harbour turned into construction areas and vegetable gardens ${ }^{24}$.

\section{Kadirga Square}

Kadirga Harbour and the shipyard were fully filled with soil in the Ottoman period and the whole area turned into residential areas, mosques, public buildings and squares known as Kadirga neighbourhood, Sokullu Mehmed Pasha Complex, Fountain of Esma Sultan and Cundi Square. The main square of this new area left from the harbour

23 Muller-Wiener, İstanbul'un Tarihsel Topografyası - 17. Yüzyıl Başlarına Kadar Byzantion-Konstantinopolis-İstanbul, 62-63.

24 Muller-Wiener, İstanbul'un Tarihsel Topografyası - 17. Yüzyıl Başlarına Kadar Byzantion-Konstantinopolis-İstanbul, 63. 
was called Kadirga Square. It could be said that Kadirga Square was located at the top part of the harbour. Although the square had no linear boundaries, surrounding avenues and streets defined the size and shape of the square. Today, these are called Kadirga Limani Avenue and Kadirga Meydani Street.

In the historical process, the main components of Kadirga Square are Uskuplu Yahya Pasha Primary School, Aci Su Fountain, Bostani Ali Mosque, Kadirga Bath, Fountain of Esma Sultan, Unnamed Fountain, Historical Kadirga Pool Cafe, Kadirga Primary School, Kumkapi Police Centre and Kadirga Vocational and Technical Anatolian High School. Particularly, Fountain of Esma Sultan is the most obvious component of Kadirga Square with its position right in the middle of the square and being constructed as a square fountain. The fountain of Esma Sultan also shows that the square's main function was still in use during the eighteenth century.

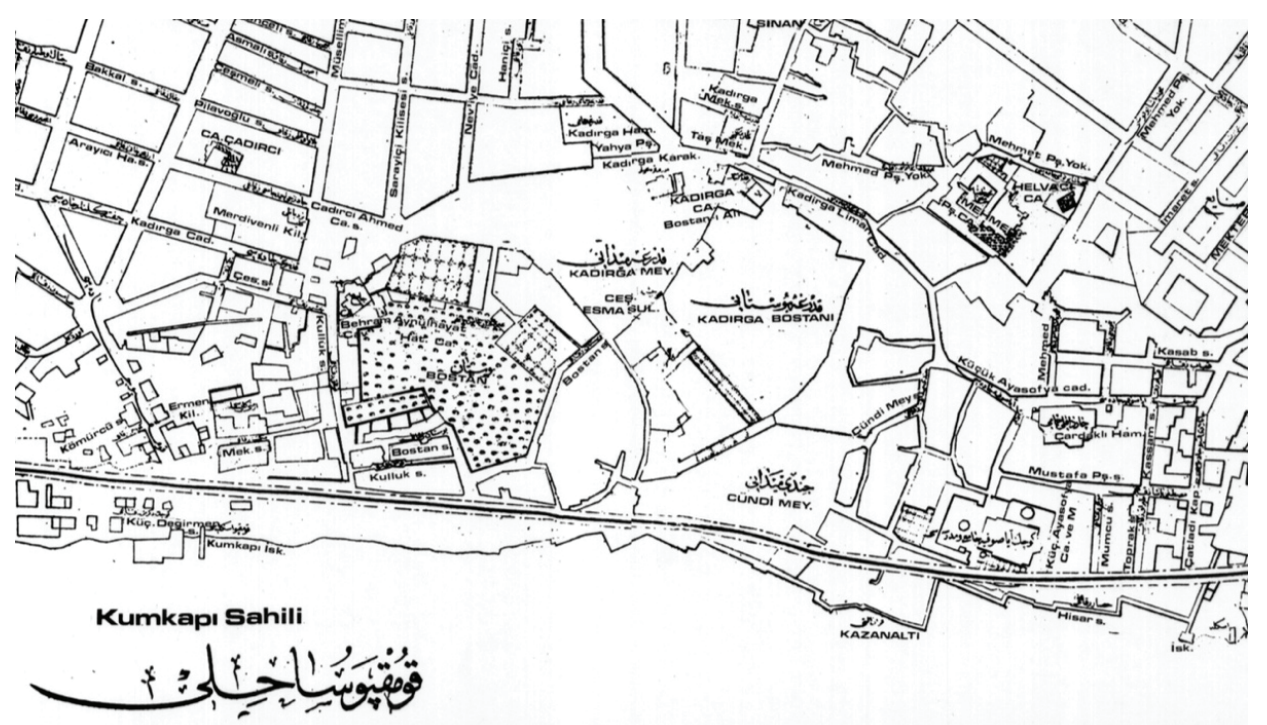

F. 4: Kadirga Square in the 1880s (Ayverdi, 19. Asırda İstanbul Haritası, B3) 


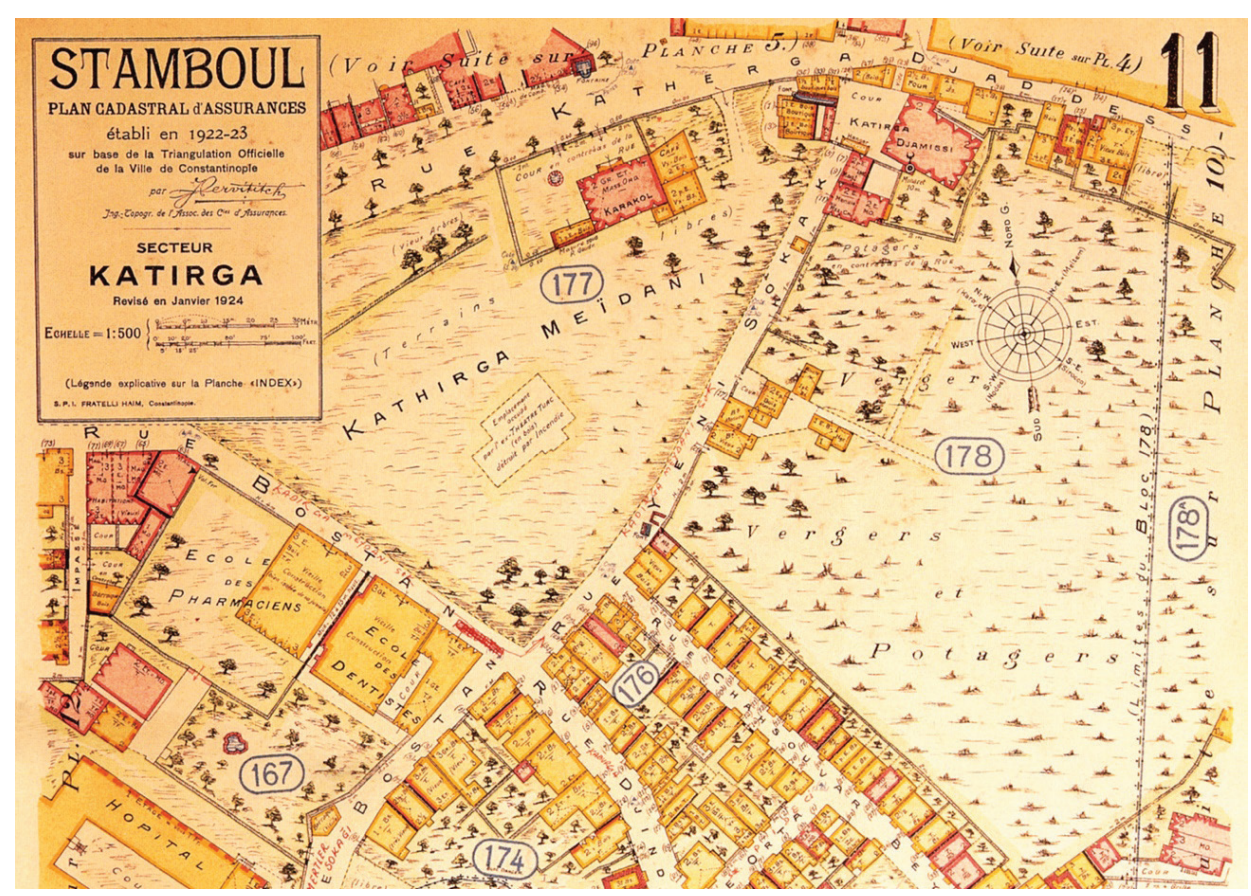

F. 5: Kadirga Square in 1924 (Pervititch, Sigorta Haritalarında İstanbul, 95)

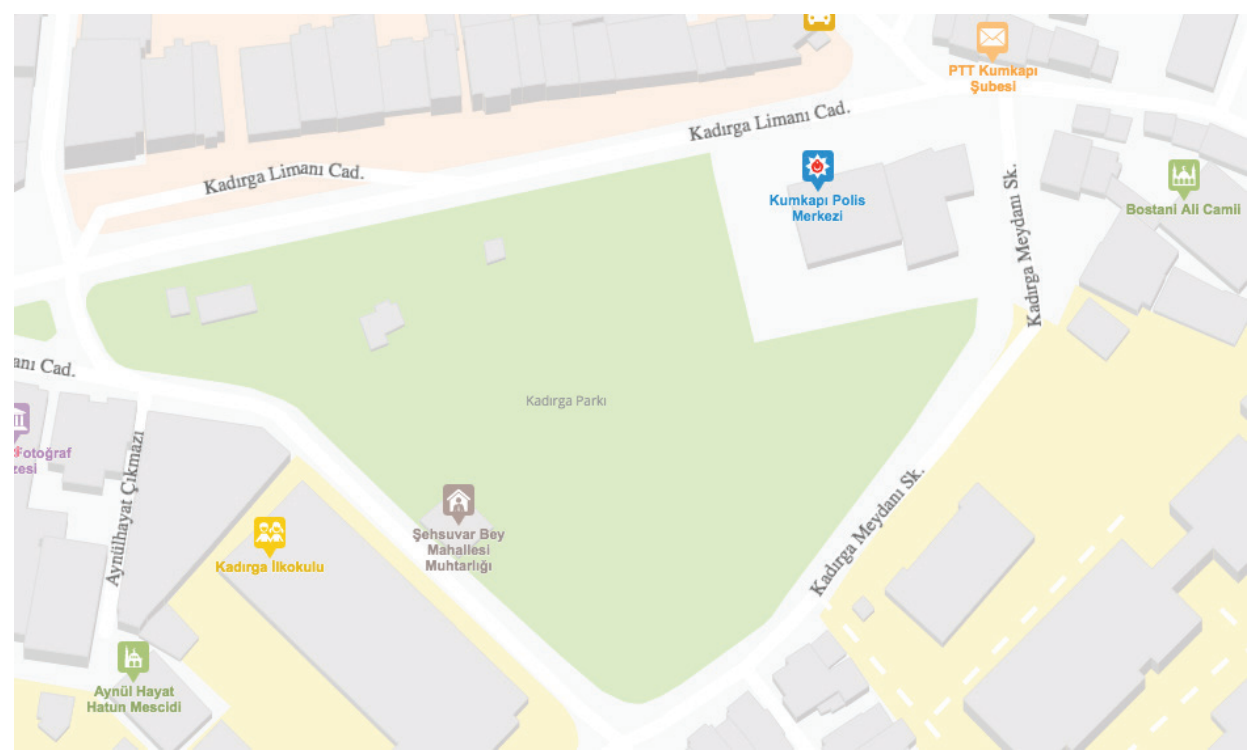

F. 6: Kadirga Park in 2020 (https://sehirharitasi.ibb.gov.tr)

Uskuplu Yahya Pasha built a primary school (sibyan mektebi) at the northeast of Kadirga Square in 1506. The school has two floors and is made of cut stone. The 
school has a square plan. However, after it was used as a printing house in later years, the inside parts were changed. There is a report from an inspection in 1913 describing that the school was being used to host Balkan immigrants. The school has a masonry structure, a large classroom, three smaller and wooden classrooms, a dining room and a garden. It was restored in between 2013 to $2016^{25}$. Today, the school is used as an auction house and an antique shop.

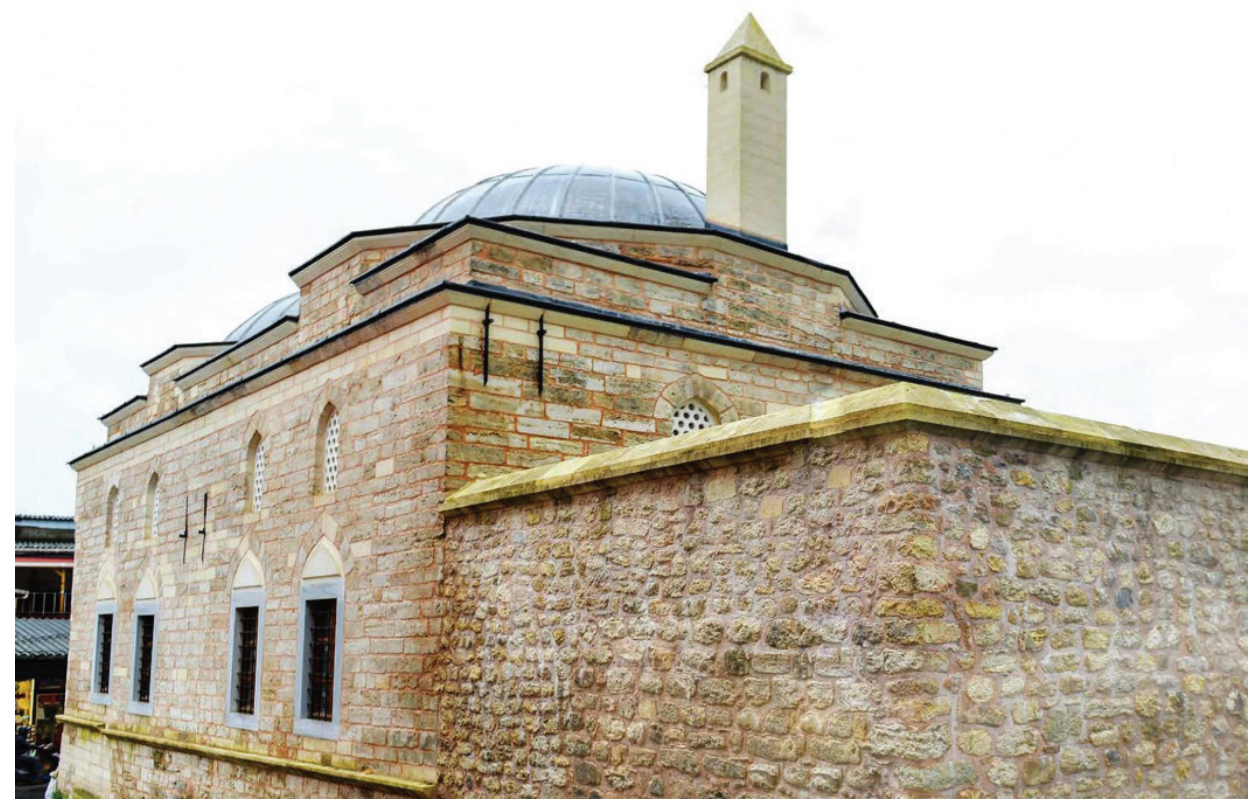

F. 7: Uskuplu Yahya Pasha Primary School in 2017

(Selvi, Fatih Belediyesi Kültürel Mirast - Ihya, 172-173)

There is also Aci Su Fountain (F. 8) at the northeast part of Kadirga Square at the intersection of Kadirga Limani Avenue and Piyer Loti Avenue. Its facade has two niches and two central arches. Although the exact date of construction is unknown, it is thought to be from the period of Architect $\operatorname{Sinan}^{26}$.

25 Necati Selvi, Fatih Belediyesi Kültürel Mirast - İhya (İstanbul: Fatih Belediyesi Yayınları, 2017), 171.

26 İstanbul Hizmet Vakfi, "Tarihî Acı Su Çeşmesi." Accessed November 15, 2020. https://www.istanbulhizmetvakfi.com/?pnum=114. 


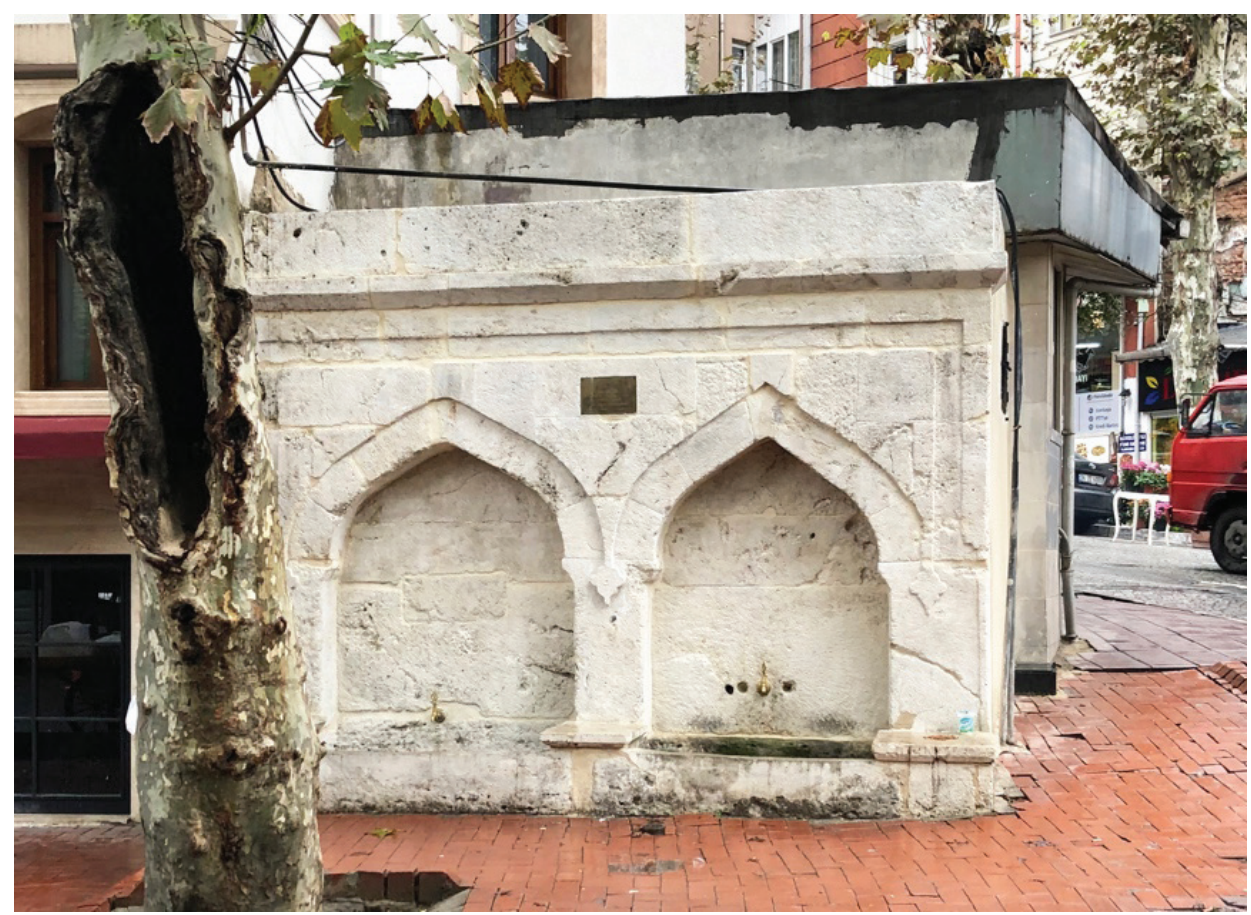

F. 8: Aci Su Fountain of Kadirga Square in 2020 (S. Çelik’s Archive, 2020)

There is a mosque in the east part of Kadirga Square and about 60 meters east of Aci Su Fountain. The mosque is called Bostani Ali Mosque (Kadirga Mosque) and was built in 1558 by Bostancibasi Ali Aga. The mosque has a square plan and is placed in a courtyard. It has a wooden roof and a thin brick minaret. There is a graveyard in front of the mosque's mihrab wall. The mosque has been repaired and restored many times and the last congregation place of the mosque was added by Architect Alaaddin Bey in 1922 $2^{27}$. Lastly, restoration of the mosque started in 2019 with plans to reopen it in 2021 .

27 Envanter Arşivi, "Bostan Ali Camii (Bostancıbaşı Ali Ağa Camii) ve Samizade Mezarı.” Accessed November 16, 2020. http://www.envanter.gov.tr/anit/kentsel/detay/48506. 


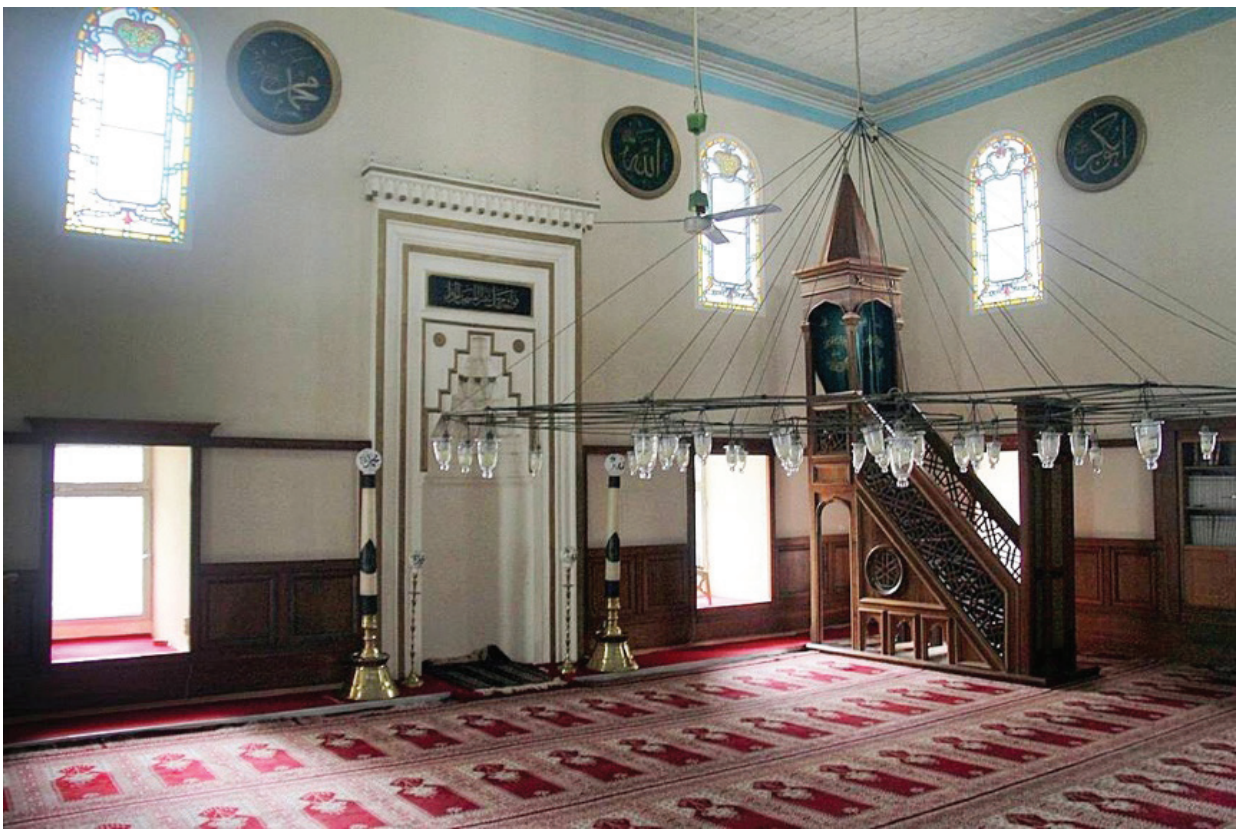

F. 9: Bostani Ali Mosque (Kadirga Mosque) in 2019

(http://www.turkiyenintarihieserleri.com/?oku=3004)

As another element of Kadirga Square, Kadirga Bath (hamam) is located at the north part on Kadirga Limani Avenue. This is a double bath (F. 10), which contains male and female sections and was built in 1734 by Vizier Yahya Pasha bin Abdulhay. However, there is also an endowment document that reports the bath was built before 1508 by Uskuplu Yahya Pasha ${ }^{28}$. Although the exact date of construction is unknown, it is known that the bath was repaired in 1948 and 1952. The women section's entry is from Piyer Loti Avenue and the bath is still in use at present. There is a square planned and domed dressing room, a three-domed warm part, a hot part with three iwans and two toilets in the men section. The women's section has the same plan as the men's section ${ }^{29}$.

28 Emine Sağlık, "Rehabilitation Project of Gedikpaşa Çilavci Street and Its Vicinity," (MA diss. Istanbul Technical University. 2000), 31.

29 Sağlık, "Rehabilitation Project of Gedikpaşa Çilavci Street and Its Vicinity," 31. 


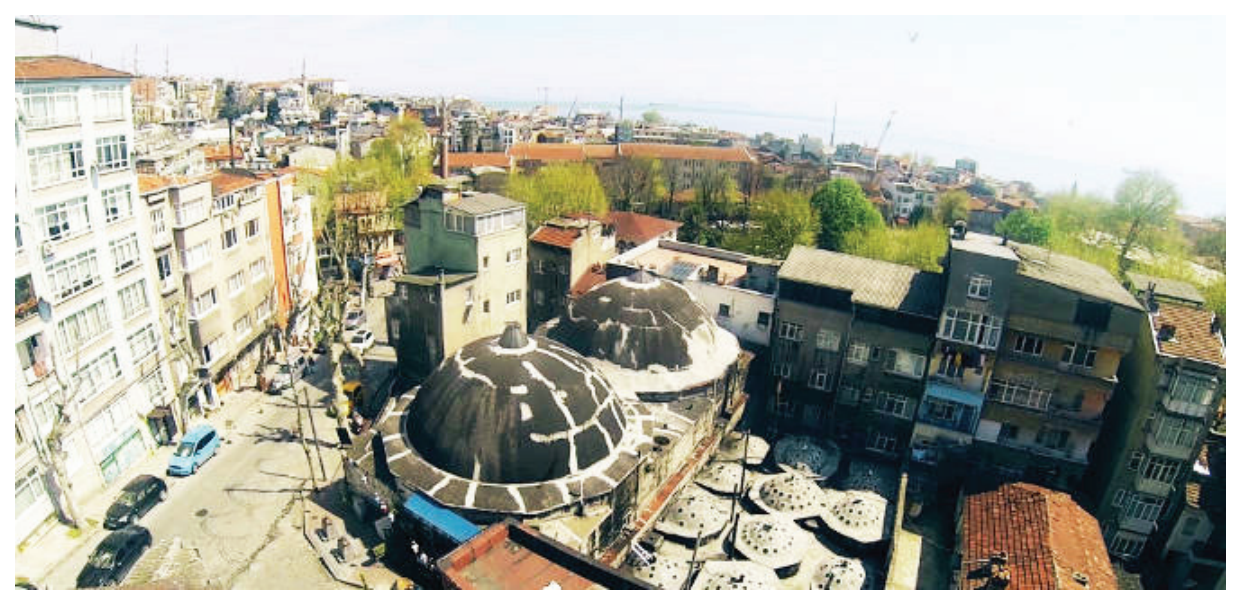

F. 10: Kadirga Bath in 2019 (http://www.kadirgahamami.com)

The distinctive feature of Kadirga Square is the fountain of Esma Sultan built in the west part of the square in 1779 . The fountain (F. 11) has four facades and also a namazgah (an open top place to pray) at the top ${ }^{30}$. Each facade has an area of $6 \times 6 \mathrm{~m}^{2}$ and creates a cube. In order to access to the namazgah above, there is a 20 -step marble staircase on the north facade. Esma Sultan, who built the fountain, is the daughter of Ahmed III ${ }^{31}$.

30 Nuran Kara Pilehvarian, Nur Urfalığlu and Lütfi Yazıcıoğlu, Osmanlı Başkenti İstanbul'da Çesmeler, (İstanbul: T.C. Kültür Bakanlığı \& YEM Yayın, 2000), 116.

31 Affan Egemen, İstanbul'un Çeşme ve Sebilleri (Resimleri ve Kitabeleri ile 1165 Çesme ve Sebil) (İstanbul: Aritan Yayinevi, 1993), 272. 


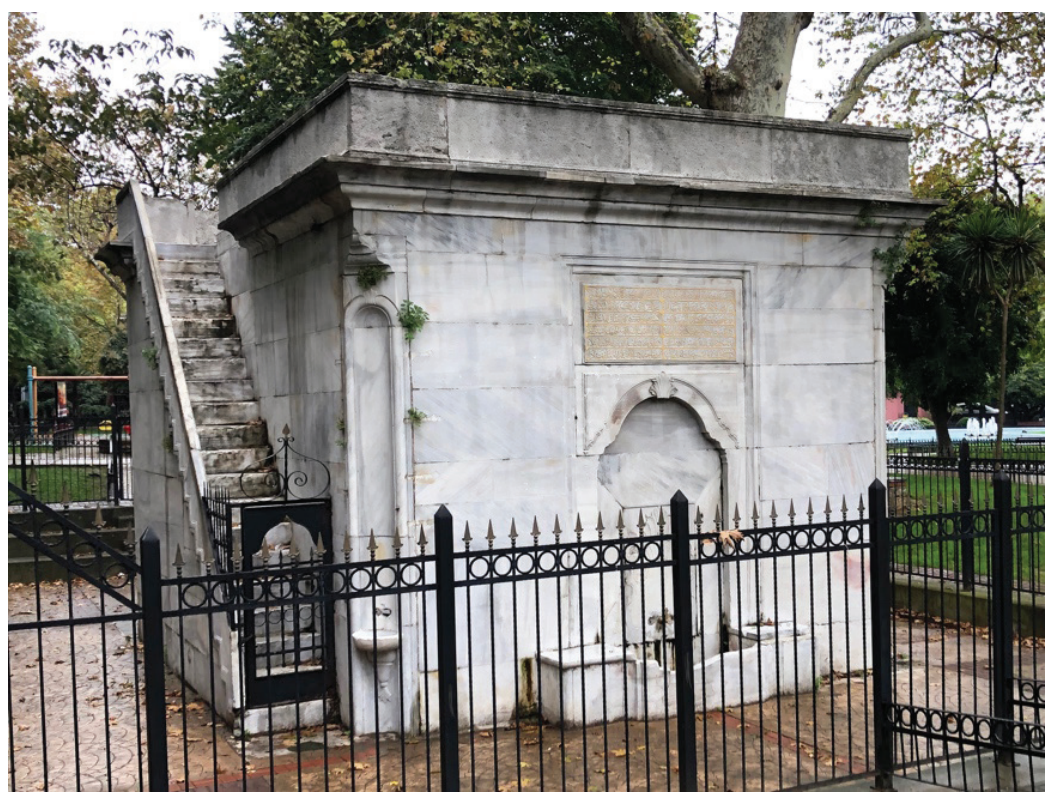

F. 11: Fountain of Esma Sultan in 2020 (S. Çelik's Archive, 2020)

There is an unnamed fountain in the northeast part of Kadırga Square. The fountain (F. 12) was rebuilt by Esseyyid Ahmed Ibnusseyyid Ahmed Halebi and Esseyyid Ahmed Halebioglu Seyyid Ahmed in $1892^{32}$. The fountain remains in front of Kadirga Vocational and Technical Anatolian High School in the present day.

32 İstanbul Hizmet Vakfi, "İsimsiz Çeşme.” Accessed November 15, 2020. https://www.istanbulhizmetvakfi. com/?pnum=112. 


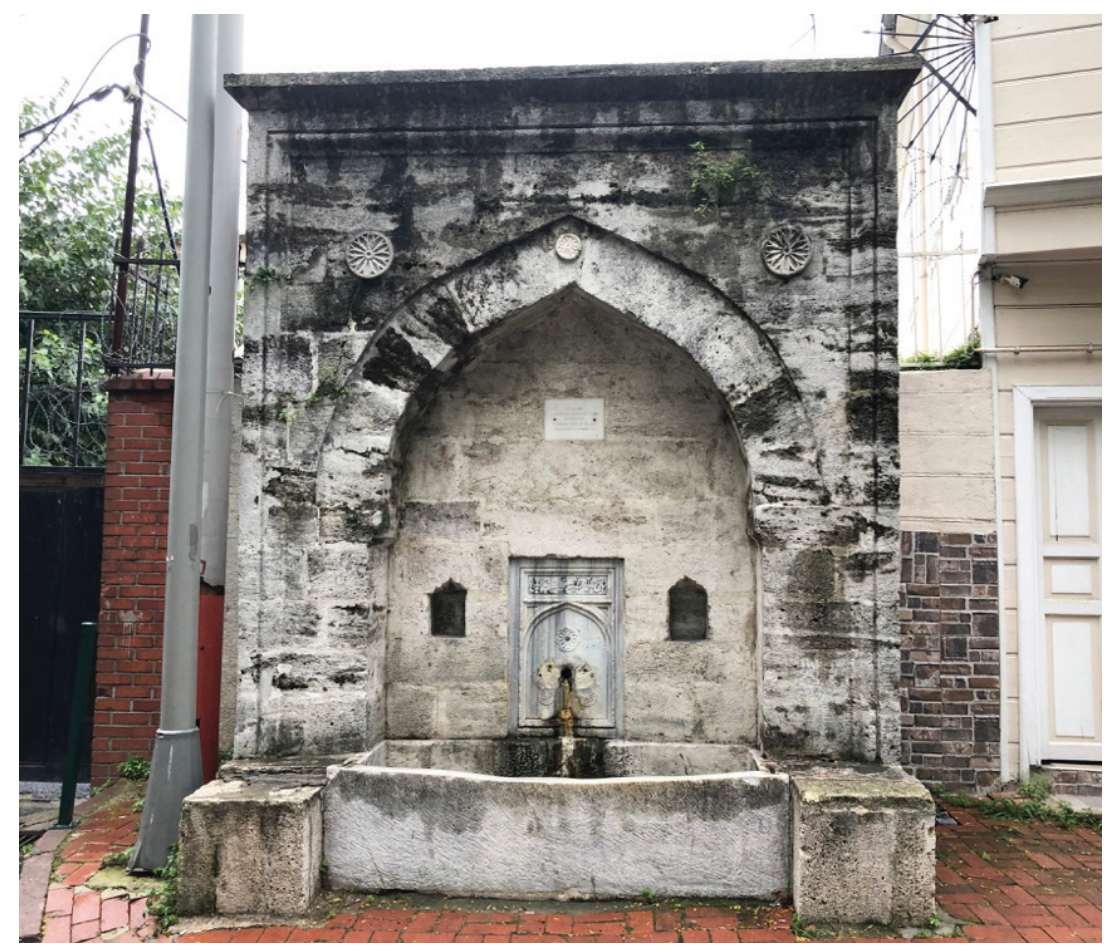

F. 12: Unnamed Fountain of Kadirga Square in 2020 (S. Çelik's Archive, 2020)

In order to make the square more dynamic, there is a cafe (kahvehane) in Kadirga Square next to the police centre. Although there are some other cafes around, this cafe (F. 13) is known as historical. It is called Tarihi Havuzlu Kahve (Historical Kadirga Pool Cafe) or Kadirga Tulumbacilar Kahvesi and was built as two wooden floors in the nineteenth century. The upper floor is the house of the cafe's owner. There is a pool in the garden of the cafe, however this part of the garden was covered with glass cases. The pool today is in the second closed area of the cafe. In addition, two facades of the cafe were renovated. In his book of Istanbul Hamamlari, M. Mermi Haskan identifies this cafe as Tulumbaci Kahvesi ${ }^{33}$. 


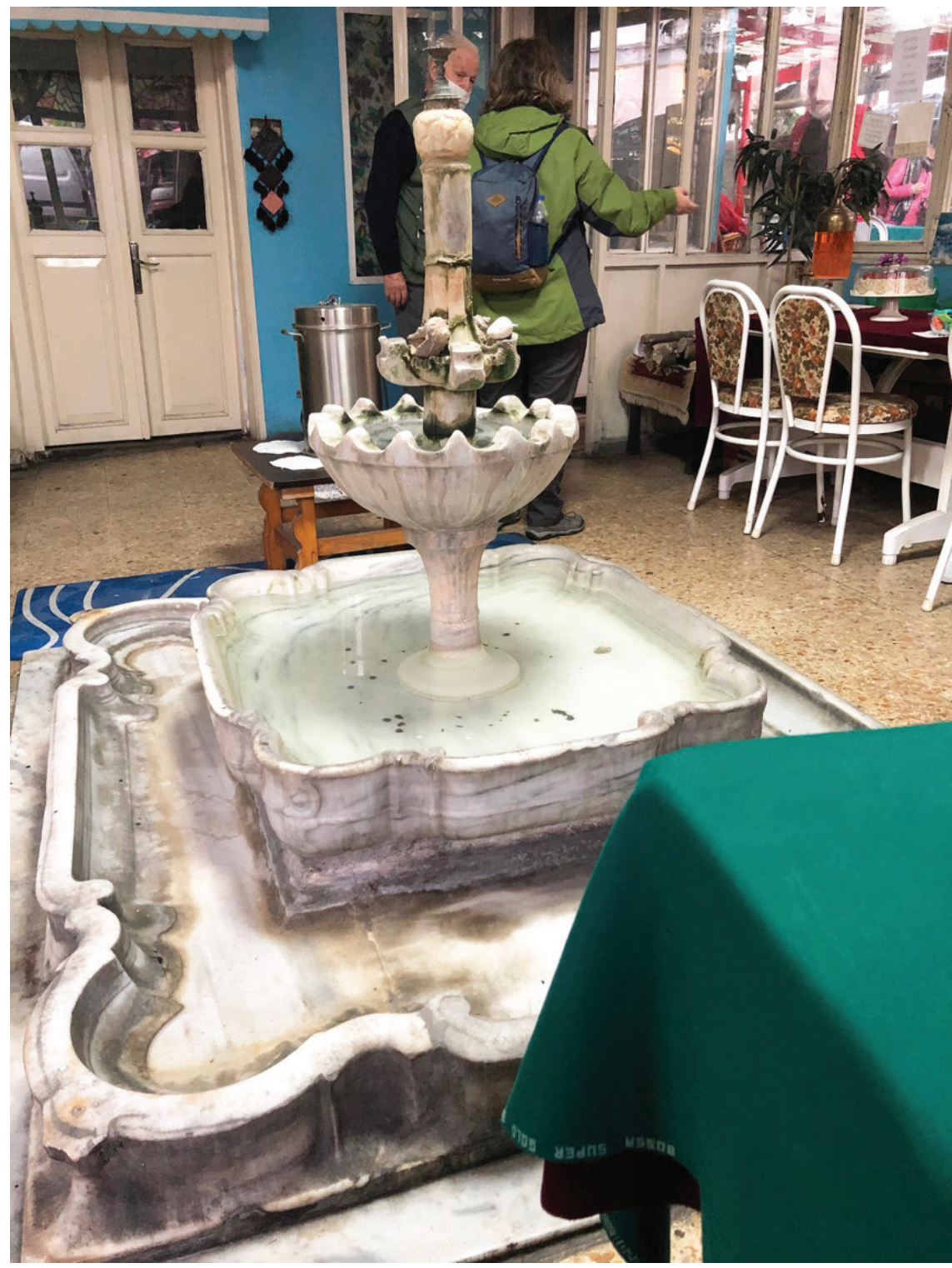

F. 13: Historical Kadirga Pool Cafe in 2020 (S. Çelik's Archive, 2020)

At the southwest side of Kadirga Square, there can be seen a few buildings next to each other on the map of Pervititch in $1924^{34}$. These buildings are together called Menemenlizade Mansion. This wooden mansion was used as a medical school, pharmacist school, dentist school, girls' art school and Vefa High School. In 1948, the mansion was turned into a primary school. In three years, another primary school 
was established in the mansion's buildings. Until 1947, these two primary schools gave education in the mansion. Unfortunately, the wooden mansion showed signs of collapse in 1947. Therefore, the two primary schools were moved from the mansion. In four years, the mansion was destroyed and a new and larger building was built for the two primary schools. The primary schools were moved to the new building in 1951. These schools were finally united as Kadirga Primary School in 1960. Kadirga Primary School (F. 14) is still in the same place today and continues to provide education $^{35}$.

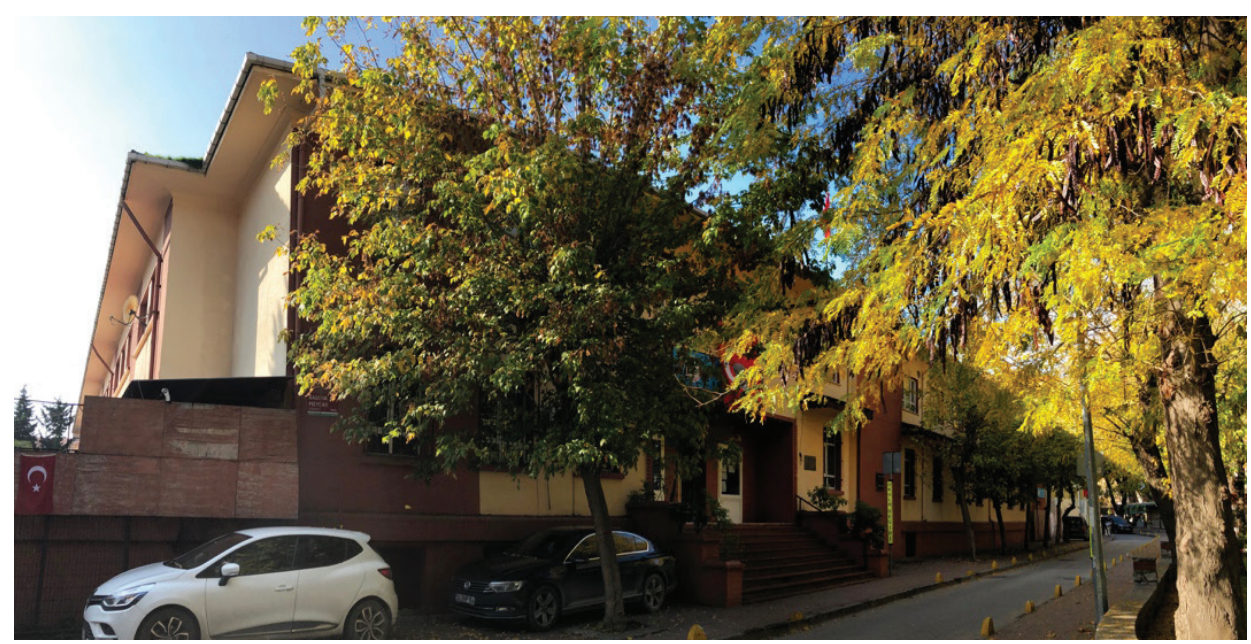

F. 14: Kadirga Primary School in 2020 (S. Çelik's Archive, 2020)

When looking at the maps of Ayverdi ${ }^{36}$ and Pervititch ${ }^{37}$, a police station (karakol) can be seen at the west of Bostan Ali Mosque and at the south of Aci Su Fountain. Today, this building on Kadirga Limani Avenue is used as a police centre called Kumkapi Police Centre (F. 15). The building has two floors and been used for other aims as well such as post office, courthouse, population management centre, and financial centre in time. It is said that the building was demolished and rebuilt. However, the first and the second construction dates of the building are not known for sure ${ }^{38}$.

35 İstanbul Fatih Kadırga İlkokulu, “İstanbul Fatih Kadirga İlkokulu Tarihçesi.” Accessed November 17, 2020. http://kadirgaio.meb.k12.tr.

36 Ekrem Hakkı Ayverdi, 19. Asırda İstanbul Haritası (İstanbul: İstanbul Fethi Derneği İstanbul Enstitüsü Yayınları, 1958), B3.

37 Pervititch, Sigorta Haritalarında İstanbul, 95.

38 Sağlık, "Rehabilitation Project of Gedikpaşa Çilavci Street and Its Vicinity," 35. 


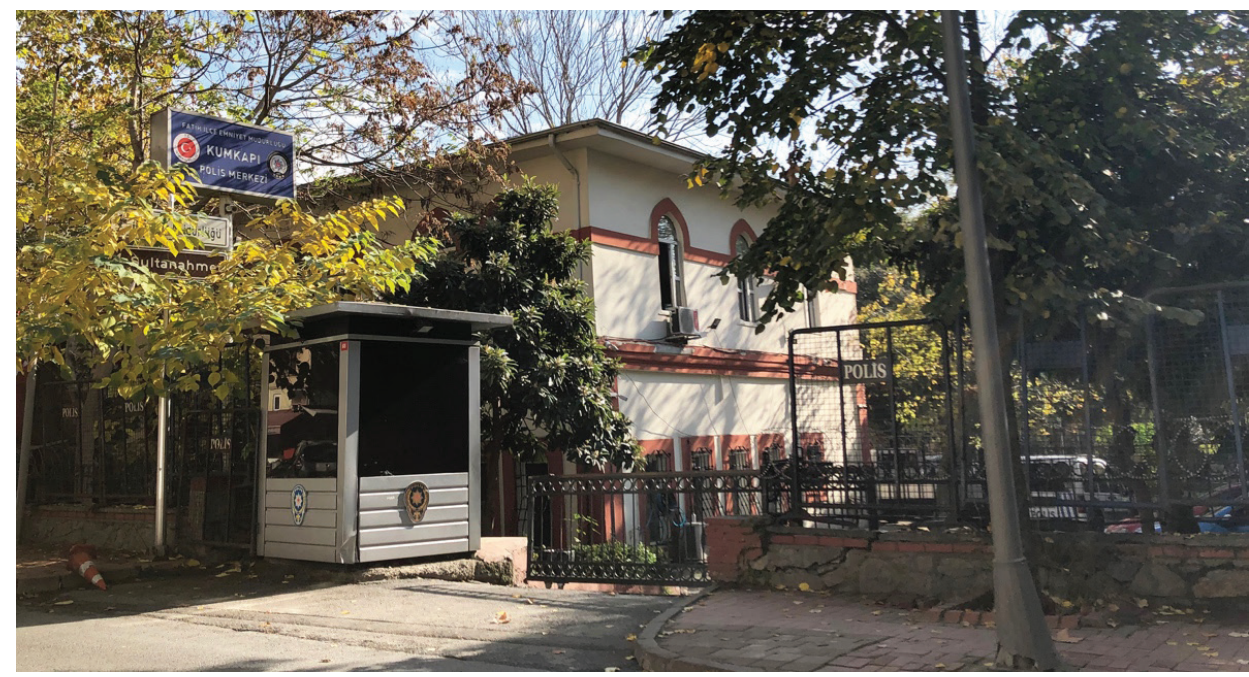

F. 15: Kumkapi Police Centre in 2020 (S. Çelik's Archive, 2020)

At the east side of Kadirga Square, Kadirga Vegetable Garden (Kadirga Bostani) can be seen on the map of Ayverdi in $1880^{39}$ and on the map of Pervititch in $1924^{40}$. In addition, it can be seen as the vegetable garden in the aerial photos of 1946-1966-1970 as well ${ }^{41}$. However, a high school complex called Kadirga Vocational and Technical Anatolian High School in the present (F. 16) (mentioned above in the unnamed fountain section) was built over the whole vegetable garden in $1977^{42}$.

Historian Eremya Celebi reports that there were Romanis living in wooden huts in Kadirga Square in the seventeenth century. However, Grand Vizier Koprulu Mehmet Pasha had the wooden huts destroyed and drove the Romanis away from the square ${ }^{43}$.

39 Ayverdi, 19. Astrda İstanbul Haritasl, B3.

40 Pervititch, Sigorta Haritalarında İstanbul, 95.

41 İstanbul Büyükşehir Belediyesi, "İstanbul Şehir Haritası.” Accessed November 18, 2020. https://sehirharitasi.ibb.gov.tr.

42 İstanbul Fatih Kadırga Mesleki ve Teknik Anadolu Lisesi, "İstanbul Fatih Kadırga Mesleki ve Teknik Anadolu Lisesi Tarihçesi." Accessed November 17, 2020. http://kadirga.meb.k12.tr.

43 Tülay Artan, "Kadırga," Dünden Bugüne İstanbul Ansiklopedisi, v. 1, (İstanbul: T.C. Kültür Bakanlığı \& Tarih Vakfi, 1994), 367. 


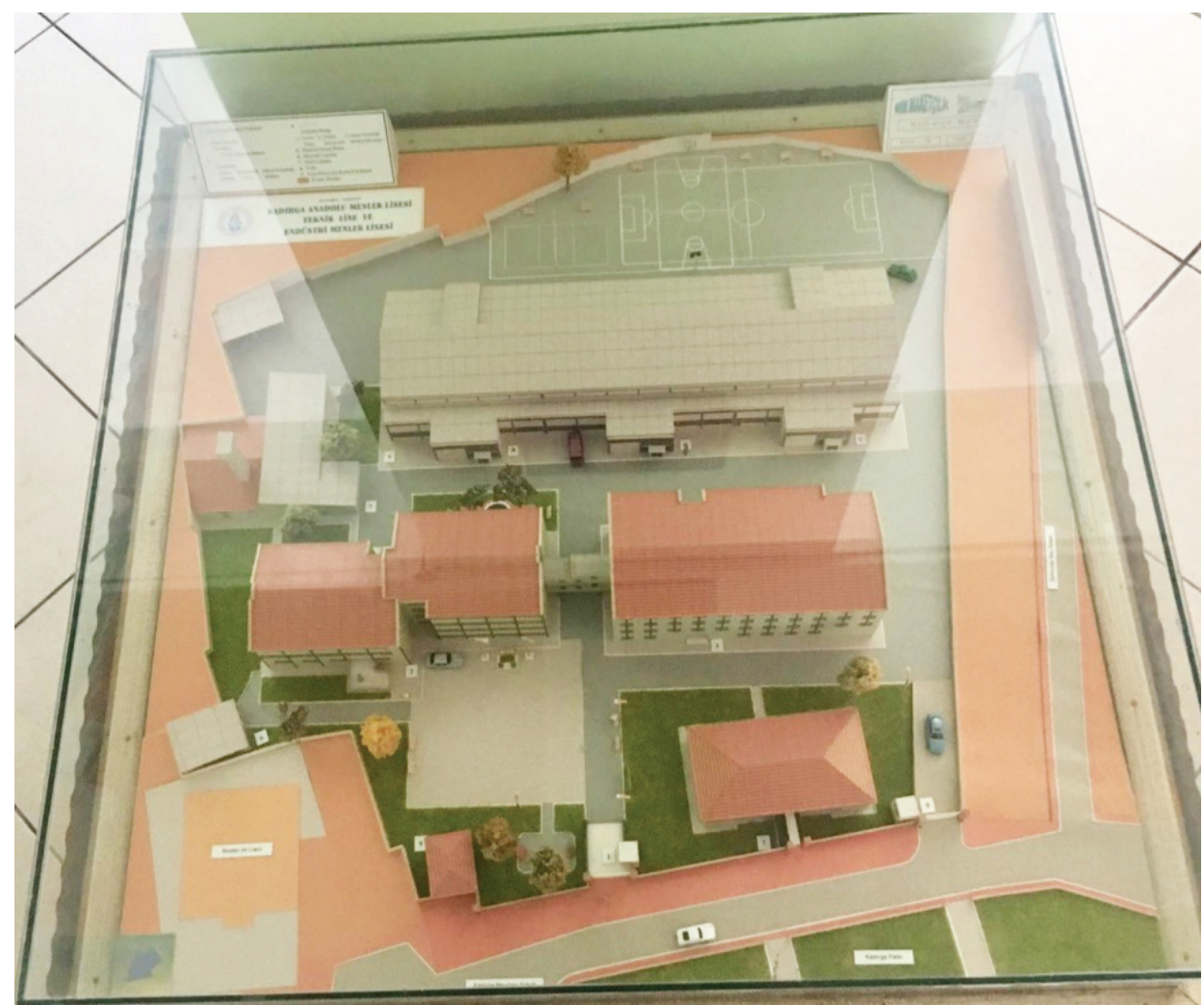

F. 16: Model of Kadirga Vocational and Technical Anatolian High School (http://kadirga.meb.k12.tr)

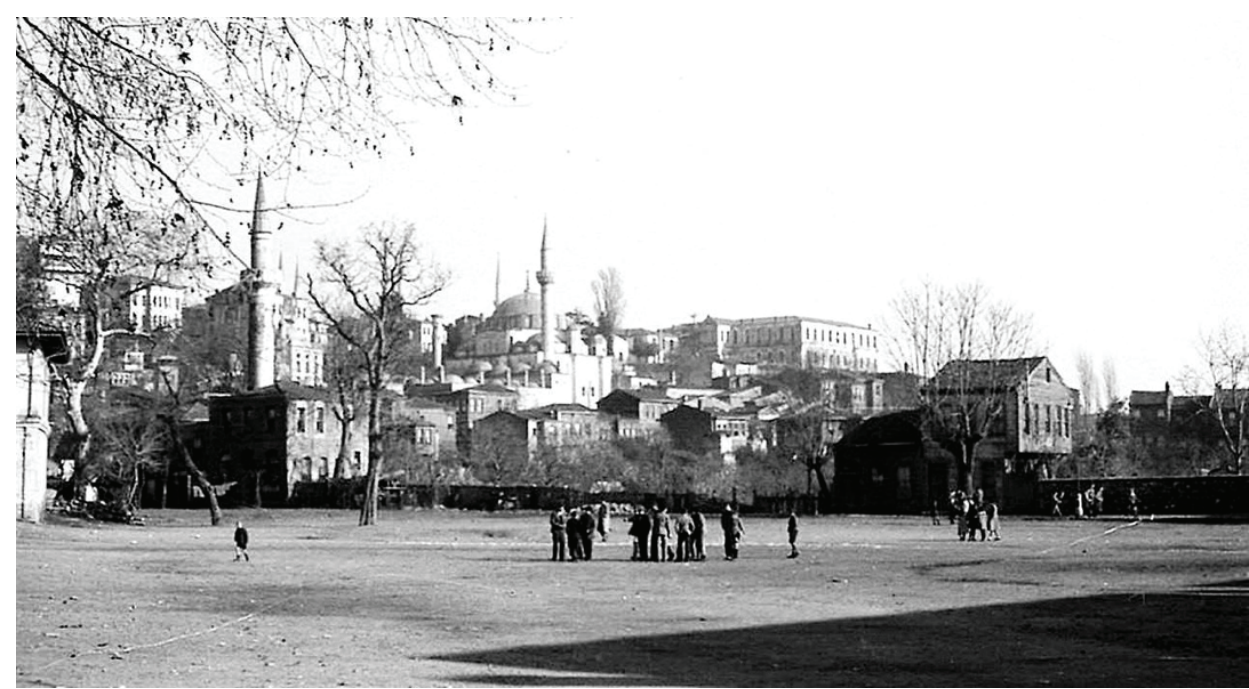

F. 17: Kadirga Square in 1943 (German Archaeological Institute's Archive, 2020) 
Apart from a few close shot photos of the fountain of Esma Sultan, there is a Kadirga Square photo from 1943 (F. 17). In the photo, a corner of the police station (karakol) building is seen on the left. Right next to that, the minaret of Bostani Ali Mosque is seen behind a two-floor wooden house. At the top, the mosque of Sokullu Mehmet Pasha and its minaret is seen behind the wooden Kadirga houses. In the centre of the photo, the border wall of Kadirga Vegetable Garden (Kadirga Bostani) and a few wooden houses in the middle of the border wall are seen. Apart from these, as the most valuable part of the photo, a large part of the Kadirga Square is clearly seen. There are some people in groups and a few trees in the square. In addition, as an important piece of information from the photo, the ground is completely soil in the 1930 s.

In the map of Pervititch in 1924, a previously burned-out wooden theatre is seen right in the middle of Kadirga Square ${ }^{44}$. However, this theatre should not be thought as Gedikpasa Theatre, because Gedikpasa Theatre is defined at a specific location different from Kadirga Square ${ }^{45}$. Playwright Musahipzade Celal describes some feast place (bayram yeri) locations in Istanbul. One of these feast place locations is Kadirga Square. According to his narratives, during the feasts, some tents were set up around the square. In a large tent, jugglers and tightrope walkers made their shows. Also, different kinds of swings called Asma Salincak, Kolan Salincak, Donme Dolap, Atli Karaca and Cek-cek Arabasi were set up in the middle of the square ${ }^{46}$. In addition, when asked, some neighbourhood residents still remember the feast place in the middle of Kadirga Square.

As a different purpose of use, the soil floor of Kadirga Square was quite suitable for playing football. Especially, the students of the schools around Kadirga Square were playing football in the square starting from $1928^{47}$. Eventually, Kadirga Sport Club was established in 1952. There is a photo of the football team of Kadirga Sport Club in the early 1950s (F. 18). On the photo, the team players are posing together in Kadirga Square where they train and play matches. Behind the players, the police station in Kadirga Square is seen. Some neighbourhood residents report that when being used as a police station, the building was given to Kadirga Sport Club for a short while and then was taken back and continued to be used as the police station again.

44 Pervititch, Sigorta Haritalarında İstanbul, 95.

45 Sağlık, "Rehabilitation Project of Gedikpaşa Çilavci Street and Its Vicinity," 8-9.

46 Musahipzade Celal, Eski İstanbul Yaşayışı (İstanbul: Türkiye Yayınevi, 1946), 96-98.

47 Babür Ardahan, “Meşhur Kadırga Meydanının Yetiştirdiği Futbolcular,” Milliyet, June 28, 1952, 5. 


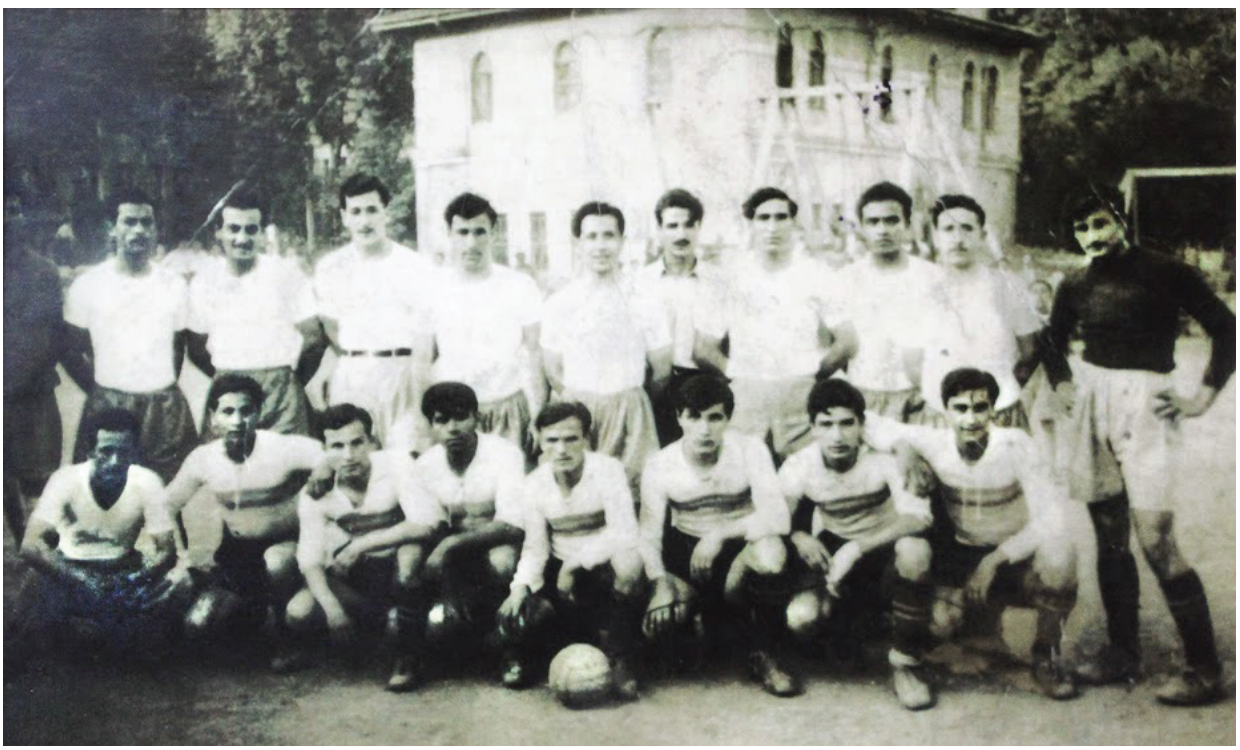

F. 18: Football Team of Kadirga Sport Club in Kadirga Square in the early 1950s

(Kadirga Sport Club's Archive, 2020)

\section{Kadirga Park}

The neighbourhood residents start to complain about Kadirga Square because of its mud in winter seasons and its dust in summer seasons in the early 1930s. They wanted the empty and dirty square to be turned into a park. Finally, they gave a complaint statement about the square to a newspaper in $1933^{48}$. After a long time, Kadirga Square's empty soil area was modified and turned into Kadirga Park in 1953. This park edition contains a children's playground and rest areas ${ }^{49}$.

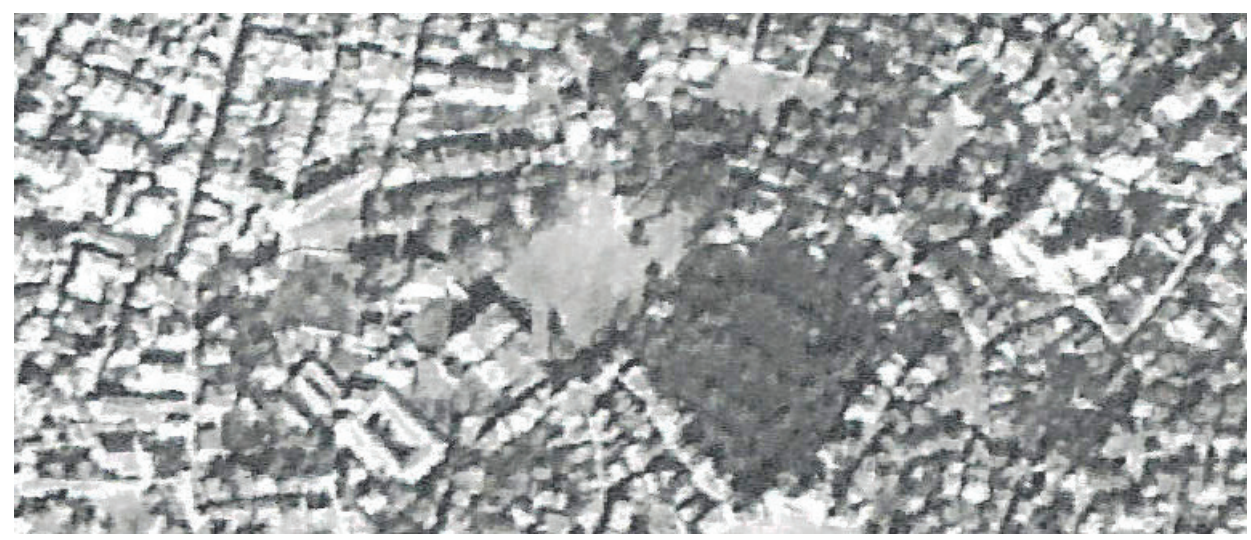

F. 19: Kadirga in 1946 (https://sehirharitasi.ibb.gov.tr)

48 "Kari Şikâyetleri: Kadırga Meydanı”, Milliyet, July 12, 1933, 5.

49 Sağlık, "Rehabilitation Project of Gedikpaşa Çilavci Street and Its Vicinity," 23. 


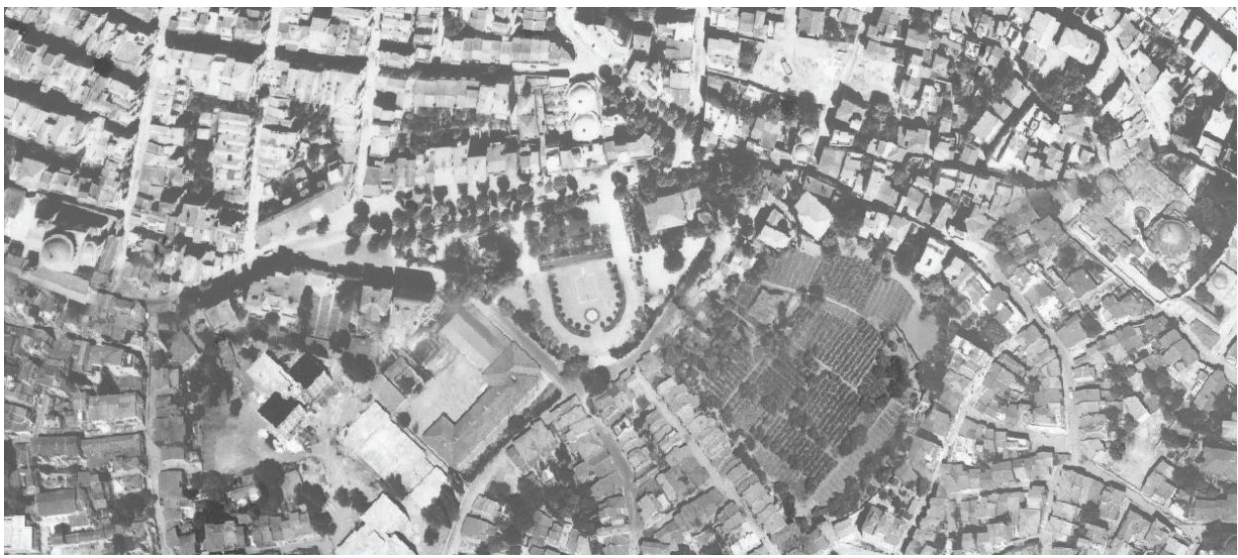

F. 20: Kadirga in 1966 (https://sehirharitasi.ibb.gov.tr)

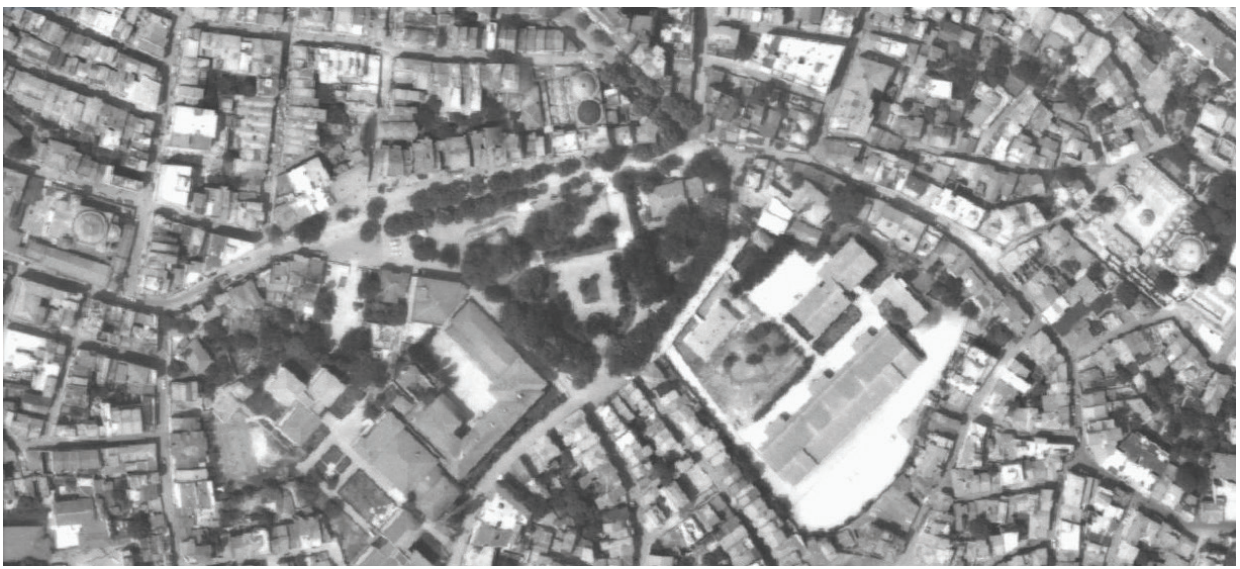

F. 21: Kadirga in 1982 (https://sehirharitasi.ibb.gov.tr)

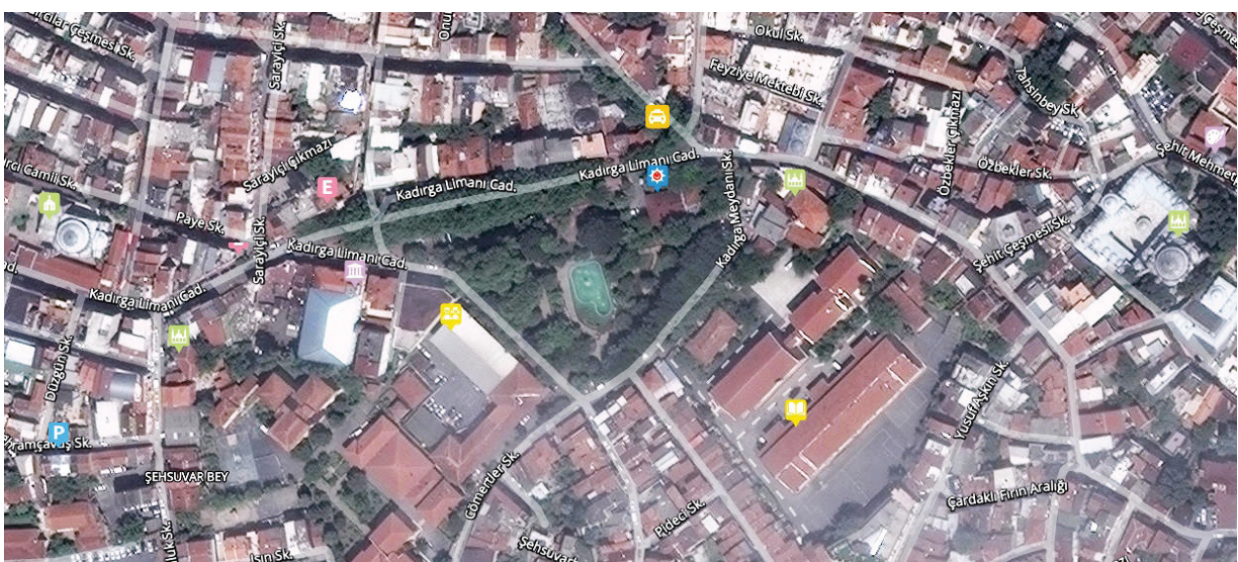

F. 22: Kadirga in 2017 (https://sehirharitasi.ibb.gov.tr) 
Apart from the old aerial photos of Kadirga, there is a photo that shows the old edition of Kadirga Park (F. 23). According to the photo, beside the trees surrounding the whole area, the main part of the park is the central area between the fountain of Esma Sultan and the police station. In this central area, plants and benches define the internal borders of the park. A sandbox (as a children's playground) and a small ornamental pool are the main elements in the central area of Kadirga Park.

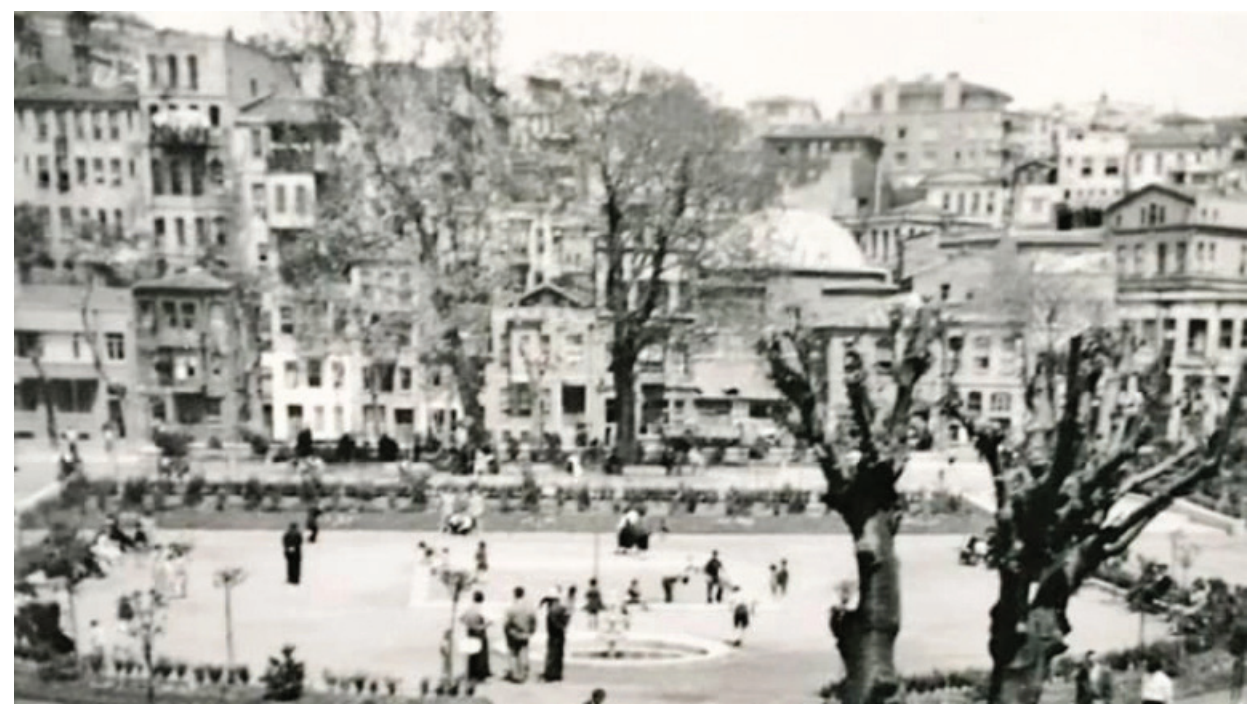

F. 23: The Old Edition of Kadirga Park (Demirok, Akşam Cumartesi, 3)

Kadirga Park is still in use today. The fountain of Esma Sultan, the police station and the historical pool cafe are inside the park area as the old elements left from Kadirga Square. Because Kadirga Limani Avenue and Kadirga Meydani Street have become the borders of Kadirga Park, Kadirga Primary School, Kadirga Vocational and Technical Anatolian High School, the Unnamed Fountain, Aci Su Fountain, Bostani Ali Mosque, Uskuplu Yahya Pasha Primary School and Kadirga Bath are left outside of the park. However, the park today has some other elements inside: Kadirga Sport Club's one-floor building (serving as a small teahouse for club members and founders behind the police station), the office building of the mukhtar of the neighbourhood (next to the fountain of Esma Sultan), Kadirga Tea Garden (serving as a small cafe next to the fountain of Esma Sultan). Apart from these, a larger ornamental pool in the middle (F. 24), a larger and modern children's playground covered with rubber floor in the north (F. 25) and more benches around the plants are located in the park today. As other important differences, the floor of the park is now paved with cobblestone and the grass fields are surrounded with black iron barriers in order to prevent deformation. 


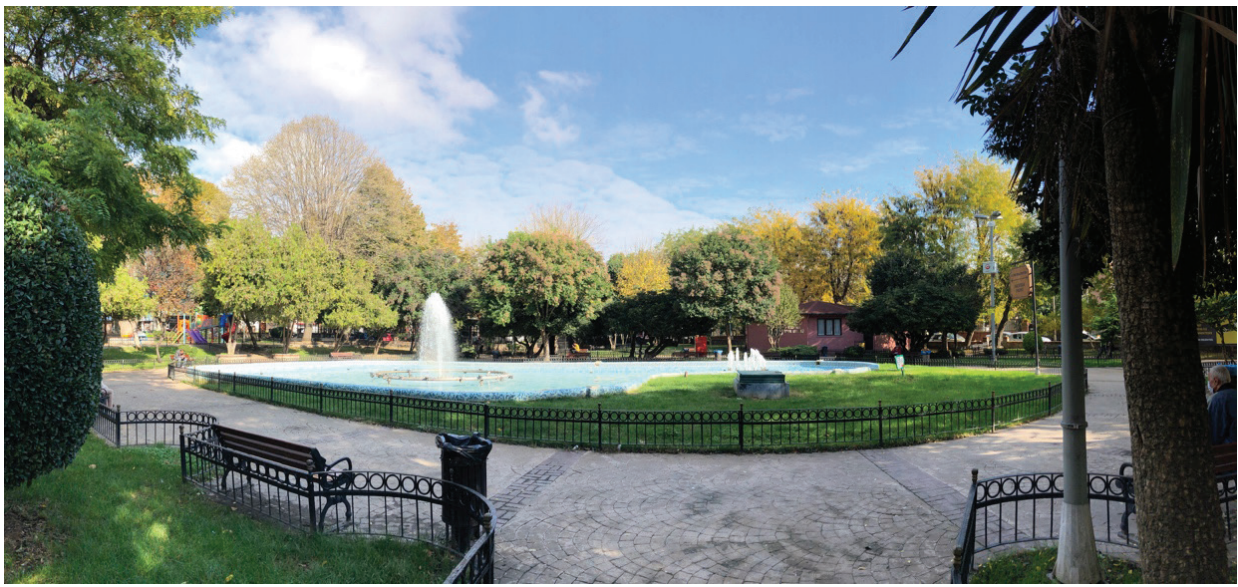

F. 24: Kadirga Park in 2020 (S. Çelik's Archive, 2020)

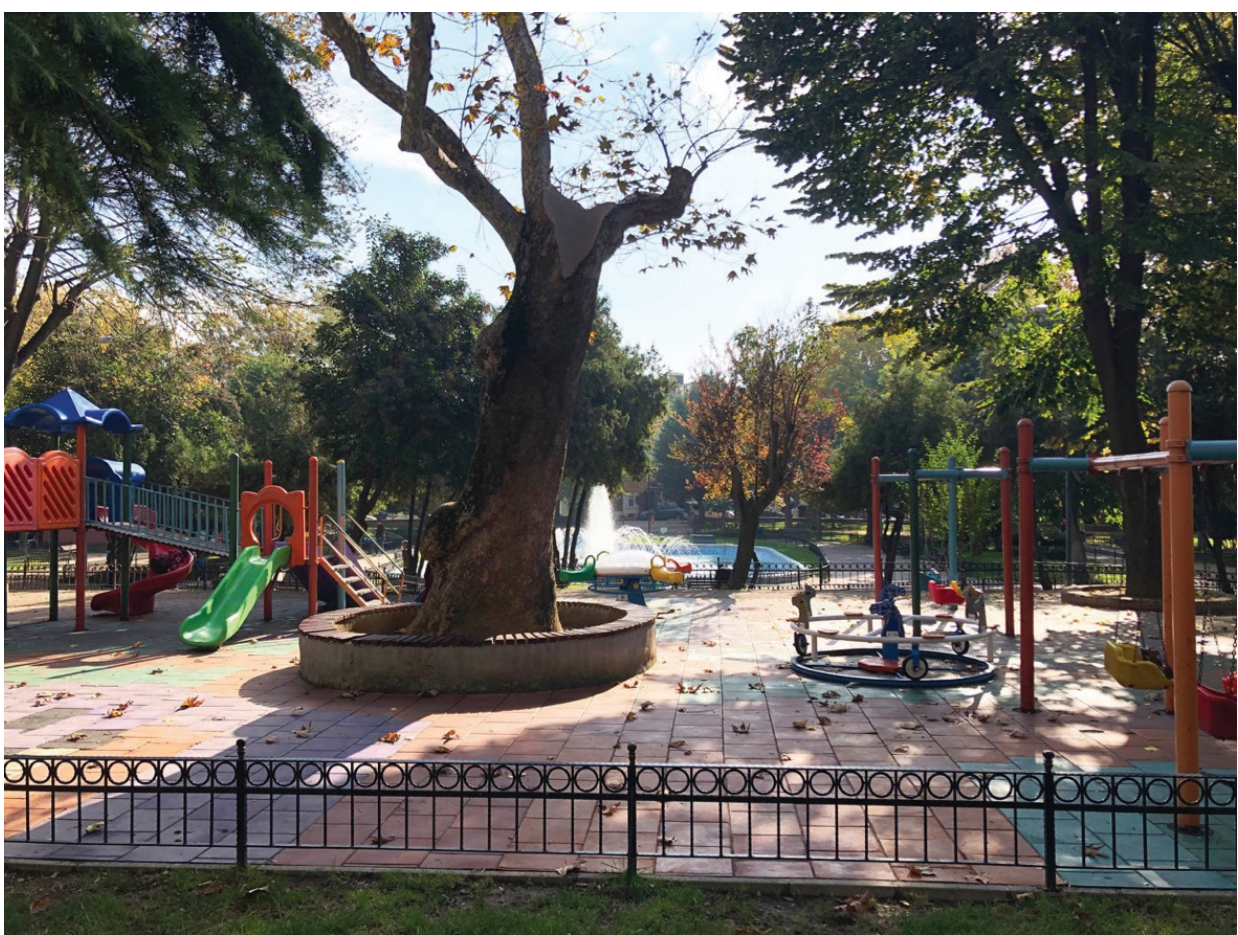

F. 25: Kadirga Park in 2020 (S. Çelik’s Archive, 2020)

\section{Conclusion}

Although it was not a planned and designed square as in the European cities, it can be clearly said that Kadirga Square was used as a square in terms of architecture. 
Because its surrounding buildings are not the first priority factors for the whole city and the size of the area is not large enough, Kadirga Square was not an urban square. However, from a neighbourhood perspective, Kadirga Square met expectations. The historical, architectural and urban process of the square, old photos, and narratives of the neighbourhood's residents are the evidence of the square's usage as an actual neighbourhood square.

A result of this study is that the neighbourhood square is a kind of the Ottoman Square. It is not very large and not defined with certain limits as in urban squares. As a square, it could meet small events and meetings in terms of local scales. Similarly, recreational and environmental contributions of the neighbourhood square are more limited compared to urban squares when there are no collective events. However, it could be said that a neighbourhood square is more frequented everyday of the year by those who live in the neighbourhood compared to urban squares. So, the neighbourhood squares are more helpful in order to socialise. As a characteristic, it could be observed that a building for the neighbourhood's benefit is necessary for a neighbourhood square in the Ottoman period, like a mosque, a fountain or a combination of these.

Like many other Ottoman squares, as long as it is used as a square, no building was allowed in the land of Kadirga Square except a square fountain. The fountain of Esma Sultan with its namazgah is a square fountain. The whole empty space of the square was used for different purposes as needed. Among them, installation of the feast place for celebration and entertainment, allowing for football matches and trainings for the development of sport can be shown. However, the important point to pay attention to is that the usage of the square is dedicated to the whole society instead of individual benefits. The demolition of the Romanis' huts in the square in the seventeenth century is a good example to the observance of the public benefit in the square.

Unfortunately, the transformation of Kadirga Square to Kadirga Park in 1953 is the starting point of losing the square in time. In the park process, the whole area of the square turned into a recreation area and the square functions were lost day by day. In the present, a park, a fountain or many fountains around are not distinguishing elements for a square. Hereby, Kadirga Square has lost its functions today. Today, the only sign of the fact that there was a neighbourhood square here before is the name of the park's surrounding street: Kadirga Meydani Street (Kadirga Square Street).

When the historical transformation process and the changing functions of Kadirga Square are evaluated, the Ottomans' square notion and neighbourhood square could be observed clearly. Kadirga Square meets the expectations of the Ottomans on a local scale and is an answer to what characteristics are essential for squares in Ottoman society. Furthermore, the square is evidence of the existence of original squares in the Ottoman period rather than a copy of European squares. 
Peer-review: Externally peer-reviewed.

Conflict of Interest: The authors have no conflict of interest to declare.

Grant Support: The authors declared that this study has received no financial support.

Hakem Değerlendirmesi: Dış bağımsız.

Çıkar Çatışması: Yazarlar çıkar çatışması bildirmemiştir.

Finansal Destek: Yazarlar bu çalışma için finansal destek almadığını beyan etmiştir.

\section{References/Kaynakça}

Ardahan, Babür. "Meşhur Kadırga Meydanının Yetiştirdiği Futbolcular.” Milliyet, June 28, 1952.

Artan, Tülay. "Kadırga.” Dünden Bugüne İstanbul Ansiklopedisi. 1. İstanbul: T.C. Kültür Bakanlığ1 \& Tarih Vakf1, 1994, 365-367.

Ayverdi, Ekrem Hakk1. 19. Asırda İstanbul Haritası. İstanbul: İstanbul Fethi Derneği İstanbul Enstitüsü Yayınları, 1958.

Braun, Georg and Franz Hogenberg. Civitates Orbis Terrarum Volume I. Cologne: 1572.

Çelik, Zeynep. 19. Yüzyılda Osmanlı Başkenti - Değişen İstanbul. İstanbul: Türkiye İş Bankası Kültür Yayınları, 2016.

Çınar Altıçekiç, Hande Sanem and Nilüfer Kart. “Kentsel Tasarım Sürecinde Meydanlar”. İstanbul Üniversitesi Orman Fakültesi Dergisi 50/2 (2000): 111-120.

Çoraklı, Selim et al. İstanbul'un İlçe ve Semt İsimleri - I. İstanbul: İBB Kültür A.Ş. Yayınları, 2009.

Demirok, İlayda. "Mahalle Geleneği Burada Yaşıyor." Akşam Cumartesi, September 19, 2020, 3.

Egemen, Affan. Ístanbul'un Çeşme ve Sebilleri (Resimleri ve Kitabeleri ile 1165 Çeşme ve Sebil). İstanbul: Arıtan Yayınevi, 1993.

Envanter Arşivi. "Bostan Ali Camii (Bostancıbaşı Ali Ağa Camii) ve Samizade Mezarı.” Accessed November 16, 2020. http://www.envanter.gov.tr/anit/kentsel/detay/48506.

Gençel, Ziya. “Geleneksel Türk Kentinde Meydan Kavramı”. Ege Mimarlık 2000/2 (2000): 22-25.

Genim, Sinan. "Meydanlar Üzerine.” Milliyet, December 8, 2013, 28.

Hasol, Doğan. “Meydan.” Aksiklopedik Mimarlık Sözlüğü. İstanbul: YEM Yayın, 2017, 320.

İstanbul Büyükşehir Belediyesi, “İstanbul Şehir Haritası.” Accessed November 18, 2020. https://sehirharitasi.ibb.gov.tr.

İstanbul Fatih Kadırga İlkokulu, "İstanbul Fatih Kadırga İlkokulu Tarihçesi.” Accessed November 17, 2020. http://kadirgaio.meb.k12.tr.

İstanbul Fatih Kadırga Mesleki ve Teknik Anadolu Lisesi, "İstanbul Fatih Kadırga Mesleki ve Teknik Anadolu Lisesi Tarihçesi.” Accessed November 17, 2020. http://kadirga.meb.k12.tr.

İstanbul Hizmet Vakfi, “İsimsiz Çeşme.” Accessed November 15, 2020. https://www. istanbulhizmetvakfi.com/?pnum=112.

İstanbul Hizmet Vakfi, "Tarihî Acı Su Çeşmesi.” Accessed November 15, 2020. https://www. istanbulhizmetvakfi.com/?pnum=114.

Kadırga Hamam1, "Kadirga Bath in 2019." Accessed November 15, 2020. http://www. kadirgahamami.com. 
Kara Pilehvarian, Nuran, Nur Urfalığlu and Lütfi Yazıcıŏlu. Osmanlı Başkenti İstanbul'da Çeşmeler. İstanbul: T.C. Kültür Bakanlığ1 \& YEM Yayın, 2000.

“Kari Şikâyetleri: Kadırga Meydanı”. Milliyet. July 12, 1933, 5.

Kayalar, Jülide. "Urban and Square - A Comparative Study of Revitalization Process." MA diss., Mimar Sinan Fine Arts University, 2006.

Krier, Rob. Urban Space. London: Academy Editions, 1991.

Kuban, Doğan. İstanbul - Bir Kent Tarihi - Bizantion, Konstantinopolis, İstanbul. İstanbul: Türkiye İş Bankası Kültür Yayınları, 2017.

Lynch, Kevin. Kent İmgesi. İstanbul: Türkiye İş Bankası Kültür Yayınları, 2010), 80.

Moughtin, Cliff. Urban Design: Street And Square. Amsterdam: Architectural Press, 2003.

Muller-Wiener, Wolfgang. Bizans'tan Osmanlı'ya İstanbul Limanı. İstanbul: Tarih Vakfi Yurt Yayınlar1, 1998.

Muller-Wiener, Wolfgang. Ístanbul'un Tarihsel Topografyası - 17. Yüzyıl Başlarına Kadar Byzantion-Konstantinopolis-İstanbul. İstanbul: Yap1 Kredi Yayınları, 2001.

Musahipzade Celal. Eski İstanbul Yaşayışı. İstanbul: Türkiye Yayınevi, 1946.

Pervititch, Jacques. Sigorta Haritalarında İstanbul. İstanbul: AXA OYAK \& Tarih Vakfi, 2001.

Sağlık, Emine. "Rehabilitation Project of Gedikpaşa Çilavci Street and Its Vicinity.” MA diss., Istanbul Technical University, 2000.

Selvi, Necati. Fatih Belediyesi Kültürel Mirası - İhya. İstanbul: Fatih Belediyesi Yayınları, 2017.

Türkiye'nin Tarihî Eserleri. "Bostani Ali Mosque (Kadirga Mosque) in 2019.” Accessed November 16, 2020. http://www.turkiyenintarihieserleri.com/?oku=3004.

Ulutaş, Ejder. "İmgeden Gerçekliğe: Kamusal Bir Mekan Olarak Meydan”. İçtimaiyat Sosyal Bilimler Dergisi 3/2 (2019): 138-146.

Y1ldiz, Aybike. "Historical Accumulations of Urban Open Space Dynamism - Istanbul Urban Example; Beyazit Square, Sultanahmet Square and Taksim Square.” MA diss., Istanbul Technical University, 2007. 
